\title{
ORIGIN OF THE SILICEOUS MOWRY SHALE OF THE BLACK HILLS REGION ${ }^{1}$
}

\author{
By WiLliam W. RUBeY
}

\begin{abstract}
The Mowry shale, a relatively thin member of hard platy shale in the lower part of the Upper Cretaceous series, is widespread throughout the northern Rocky Mountain States. Its peculiar lithologic characteristics are due chiefly to its hardness, which in turn is caused by the presence of a large amount of silica. The problem of the origin of this silica is thus a fundamental problem in the origin of the Mowry shale. In the present paper the discussion of the probable origin of this silica is developed by considering the significance of each type of evidence as it is stated, instead of by the usual method of first completely describing and then interpreting the observed facts.

Field, chemical, and microscopic evidence indicates almost certainly that the silica in the Mowry shale was in some way derived from the alteration of volcanic ash. As a probable method of this derivation, it is suggested that the original ash was unusually siliceous, that it was decomposed by long exposure to sea water, and that silica dissolved from it was precipitated by decaying organic matter. A minor amount of secondary silicification may have occurred during consolidation and weathering. The iew siliceous tests of organisms found fossilized in the shale are considered merely incidental constituents of the shale. The small amounts of clay, silt, and sand in the shale may be in part more or less altered volcanic products and in part normal clastic sediments.

Whatever may be the method of derivation of the silica, the mere presence of large quantities of volcanic ash in the Mowry shale is stratigraphically significant, for it increases confidence in the reliability of the member for purposes of correlation.
\end{abstract}

\section{ACKNOWLEDGMENTS}

The writer gratefully acknowledges the valuable advice, suggestions, and criticisms freely accorded to him in this study by many fellow-members of the United States Geological Survey. C. S. Ross, R. C. Wells, J. B. Reeside, jr., and J. D. Sears have been especially helpful, but a number of others, only a few of whom are mentioned in the text, have furnished materials and information that are an essential part of the paper.

\section{FIELD OBSERVATIONS}

The Mowry shale is well known to geologists who have worked in the Cretaceous rocks of the northern Rocky Mountain States. Its abundance of fish scales, unusual silvery-gray color, porcelaneous hardness where weathered, excellence as a natural base for automobile roads, topographic prominence, and great

\footnotetext{
1 Paper presentod beforo the Creological Society of Washington Feb. 9, 1927 (The origin of the Mowry shaje: Washington Acad. Sci. Jour., vol. 17, p. 235 (abstract), 1927).
}

areal extent make it easily recognizable and extremely useful for correlation. It has been recognized in Wyoming, Montana, western South Dakota, and northern Colorado. ${ }^{2}$ Throughout most of Wyoming it lies between the Thermopolis shale and the Frontier formation and is from 100 to 300 feet thick, ${ }^{3}$ but it thickens southwestward, and in extreme southwestern Wyoming the Aspen formation, locally more than 2,000 feet thick, ${ }^{4}$ occupies the stratigraphic position of the Mowry shale and, according to current interpretations, of some lower beds, and has the same fauna and lithologic character. $^{5}$ In its type locality near Buffalo, Wyo., ${ }^{6}$ and elsewhere to the north and west, the Mowry consists of hard shale and thin sandstone, but southward and eastward little sandstone is present.

\section{STRATIGRAPHIC RELATIONS AND LITHOLOGY OF MOWRY SHALE}

Where the Mowry shale is turned up around the northwest flank of the Black Hills uplift in northeastern Wyoming, it consists of 100 to 150 feet of hard shale in the lower part of the Graneros shale. Here it makes a continuous hogback that is generally pinecovered but supports little grass, and the bare ground is made up of hard platy silvery-gray ${ }^{7}$ chips of shale. (See pl. 14, A.) In fresh exposures the Mowry is seen to consist of moderately thin bedded, exceptionally hard shale with a few thin layers of very fine grained sandstone. It is interlaminated with beds of bentonite from less than 1 inch to more than 1 foot thick. Although bentonite beds occur throughout the Cretaceous rocks of the region, they are especially abundant in the upper part of the Mowry shale, but even at this horizon they constitute only a small proportion of the total thickness. Where unweathered the shale is black or very dark gray and shows a dull earthy luster, but on weathered surfaces it is light bluish gray. or even

${ }^{2}$ See Geis, W. H., The origin of light oils in the Rocky Mountain region: Am Assoc. Petroleum Geologists Bull., rol. 7, fig. 1, p. 481, 1923, for a map of the distribution of the Mowry shale.

? Wilmarth, M. G., Tentative correlation of gcologic formations in Wyoming ( separate chart), U. S. Geol. Survey., A pril, 1925.

- Veatch, A. C., Geography and geology of a portion of southwestern Wyoming: U. S. Geol. Survey Prof. Paper 56, pp. 64-65, 1907.

$\checkmark$ Reeside, J. B., jr., personal communication.

- Darton, N. H., Geology and underground water resources of the central Great Plains: U. S. Geol. Survey Prof. Paper 32, p. 187, 1905.

' 7 At Red Hill, in secs. 5 and 6, T. 54 N., R. 66 W., near Missouri Buttes, in Crook County, Wyo., the Mowry sbale is conspicuously red, but the red color is cloarly a result of the inflitration of iron oxides from red clay in the overlying White River (?) deposits. 
white and has a glazed appearance under the hand lens. The fracture is commonly subconchoidal. (See pl. 14, $B$.) The hardness or crushing strength of the shale is such that it resists crushing in the hand or between the teeth, but even the hardest pieces are readily scratched with a knife. On the mineral scale the shale commonly has a hardness of 3 to $4 .^{8}$ Although apparently regularly bedded, the numerous planes of jointing or fissility that simulate bedding are not strictly parallel, and on close examination these planes suggest concretionary structure. True concretions, however, are rare, even in the few localities where the beds contain calcite. In some places the joint planes are stained yellow and brown, presumably with iron oxide.

Near the Black Hills the Mowry shale member of the Graneros shale overlies by gradational contact 5 to 50 feet of soft shale which Collier has named the Nefsy shale member. ${ }^{9}$ The Nefsy in turn lies upon the Newcastle sandstone member, ${ }^{10}$ a variable unit of sandstone, shale, lignite, bentonite, and phosphatic nodules from a few inches to 75 feet thick. The Mowry underlies, with sharp lithologic change, the Belle Fourche shale member ${ }^{11}$ of the Graneros, a partial equivalent of the Frontier formation of western Wyoming. The Belle Fourche member consists of 450 to 850 feet of soft dark shale that in its upper part contains bentonite beds and many calcareous concretions. The lower 25 to 200 feet contains abundant concretions of manganiferous siderite about a foot in diameter, and this zone forms a low scarp near the Mowry hogback. The contact between the soft dull-gray concretion-bearing shale of the Belle Fourche and the hard shale of the Mowry is further emphasized by a persistent bed of bentonite from 1 to 4 feet thick at the top of the Mowry shale. This bed was traced 175 miles along its outcrop in northeastern Wyoming, and it can be recognized with reasonable certainty in South Dakota beyond the limits of this mapping.

As elsewhere throughout its area of distribution, the Mowry shale of the Black Hills contains many fish scales (see pls. $14, B ; 15, A, B$ ), some bone fragments, and an exceedingly sparse invertebrate. marine fauna quite similar to that of the Greenhorn formation, which in this region immediately overlies the Belle Fourche member of the Graneros. In fact, so similar are the two faunas that there is reason for considering the assemblage an environmental facies that indicates simply Benton age. ${ }^{12}$ Some fragments of Mowry shale contain a few hollow but well-preserved molds or shells of Radiolaria of the suborder Nasselaria (and Spumellaria?). (See pl. 16, A.) These small pits, about 0.1

\footnotetext{
S Sec Kindle, E. M., A proposed scale of hardness and cohesion for rocks: Rosearches in sedimentation in 1925-26, pp. 95-97, National Research Council, 1926.

- Collier, A. J., The Osage oil field, Weston County, Wyo.: U. S. Geol. Survey Bull. 736, p. 82, 1922 .

${ }_{10}$ Hancock, E. T., The Mule Creek oil field, Wyoming: U. S. Geol. Surrey Bull. 716, p. 42,1920 .

11 Collier, A. J., op. cit., p. 83

12 Reeside, J. B., jr, personal communication.
}

millimeter in diameter, are best seen on fresh surfaces of the shale. In no specimens were these fossils common, and even in thin sections cut especially to examine as many radiolarians as possible, they constituted less than 5 per cent of the rock. No diatoms or foraminifers were noted in the many specimens examined under binoculars.

The very dark color of fresh Mowry shale and the hard light-gray and laminated surface of the weathered rock suggest that it may be an impure oil shale, and in fact it has been reported as such elsewhere. ${ }^{13}$ However, crude heating tests on typical sảmples of the Mowry shale from the Black Hills region gave little indication of the presence of bituminous matter, and E. T. Erickson, of the Geological Survey, estimated their content of oil at less than 1 gallon to the ton. A sample of Mowry shale from sec. 35 , T. 57 N., R. 66 W., Crook County, Wyo., analyzed by the Bureau of Mines, Department of Commerce, contained only 0.07 per per cent of organic matter soluble in chloroform.

\section{HARDNESS OF THE SHALE DETERMINES OTHER CHARACTERISTICS}

Many and possibly all the peculiar characteristics of the Mowry shale of this region are closely related to or even caused by its exceptional hardness or crushing strength, and this hardness, as discussed in another part of this paper, is shown by chemical analyses to be almost certainly due to unusual amounts of silica. The topographic prominence of the Mowry and the absence of soil at its outcrops are directly the result of its hardness and resistance to weathering. The hard and smooth yet never slippery surface of roads where its exposures are crossed can be explained by its induration, freedom from irregularities of hardness, and binding qualities. ${ }^{14}$ The light-gray color so typical of the outcrops of Mowry shale is also in large part the result of resistance to weathering, for the dark organic material is removed more rapidly than the rock disintegrates. The most widely known characteristic of the Mowry shale-the apparently unusial abundance of fish scales-may be only an apparent peculiarity caused by its hardness. The writer has found fish scales equally abundant on fresh surfaces of shale in many other beds in the Graneros of the Black Hills region, and it is quite possible that scales are conspicuous in the Mowry shale simply because the rock disintegrates very slowly. As is pointed out in this paper, other characteristics of the Mowry shale, such as its association with bentonite, may also be indirectly related to its hardness.

${ }^{13}$ Collier, A. J., The Bowdoin dome, Mont.: U. S. Geol. Survey Bull. 661, p. 199 1918. Geis, W. H., The origin of light oils in the Rocky Mountain region: Am. Assoc. Petroleum Geologists Bull., vol. 7, pp. 499-500, 1923. Reeves, Frank, Geology and possible oil and gas resources of the faulted area south of the Bearpaw Mountains, Mont.: U. S. Geol. Survey Bull. 751, p. 107, 1924.

14 Shown by binder tests made by Bureau of Public Roads, Department of Agriculture, on samples collected by the writer. Comparison with tests on other shales of the Black Hills region suggests that the binder or cement is silica. 


\section{VARIATIONS IN HARDNESS}

The hardness or silica content of the shale thus assumes an importance which led the writer during several scasons' work in the region to make observations that might suggest its cause.

The most obvious variation in hardness is a vertical one that extends throughout the member; the Mowry shale is softest in the lower part and hardens progressively upward. The lower part is so soft that mapping of the thin, soft Nefsy shale between the Mowry and Newcastle members had to be abandoned, for at only a few places could a satisfactory boundary be chosen between Mowry and Nefsy, and in most exposures the rather uniform increase in hardness upward showed the two members to be but parts of one lithologic unit.

A second relation observed is that the shale is harder inmediately below interlaminated bentonite beds. This relation, though generally inconspicuous, was noticed in 1922 and tested at every later opportunity, and the writer is now convinced of its truth as a generalization. Hardening of beds adjacent to bentonite was noted also at several places in the Belle Fourche and Picrre shales of the same region. The most striking cxample of hardened strata near bentonite beds is $n$ hard bed of partly altered tuff $11 / 2$ feet thick at the top of an 18-foot bentonite near the base of the Pierre in the vicinity of Pedro, Wyo. Microscopic cxamination and chemical analyses show that the only important difference between this tuff and the bentonite is the larger amount of very finely divided silica in the tuff. The writer has also noticed thin and very hard beds in bentonite in the Thermopolis shale near the Pryor Mountains, in south-central Montana; and hardened shale near bentonite beds is reported from Virginia, Kentucky, and Mexico. ${ }^{15}$

The combined effect of the two relations just mentioned is that the softest shale is in the lower part of the member, the hardest is just below the thick bentonite bed at the top, and the hardening upward is interrupted slightly at each intervening bed of bentonite. This stratigraphic distribution of hardness may be made clearer by a specific example. Chemical an alyses show that the amount of contained silica varies with the hardness of samples, although doubtless a soft sandy layer might contain more silica than a hard shale. Analyses of samples collected near Thornton, Wyo., show a silica content of 84.14 per cent in a weathercd sample from 5 to 10 feet below the top of the Mowry shale and of 75.62 per cent in a fresh fragment immediately below a thin bentonite about 25 feet below the top of the member. Rough crushing tests of these and other analyzed specimens and of other samples of the shale led the writer to estimate that at Thornton the silica content of the fresh shale in the lower few fect of the overlying Belle Fourche is 55 to 60 per cent, at the top of the Mowry 80 to 85 per cent,

is Ross, C. S., personal communication.

$100874^{\circ} \ldots 29-11$
75 feet below the top 65 or 70 per cent, and at the base of the Nefsy member about 55 per cent. This sequence is interrupted by increases of 5 per cent or more at the bases of other bentonite beds.

A third relation is an apparent geographic variation in the hardness of the Mowry shale. In the southeastern part of the Black Hills uplift, between Hermosa and Edgemont, S. Dak., the Mowry shale is inconspicuous or absent. As the member is recognized largely if not entirely by its hardness, its apparent absence to the southeast is probably the result of decreased hardness in that direction. Elsewhere about the Black Hills the Mowry shale seems to increase in hardness westward and to reach its maximum induration and topographic prominence near Upton and Thornton, Wyo. It is interesting to note that this direction of hardening coincides with the direction of the source of the bentonite at the top of the Mowry shale, as indicated by the thickening of the bed and the increase in size and amount of contained sandsized particles. These sand-sized particles are essentially the phenocrysts which crystallized in the magma before the eruption of the volcanic ash that has been changed to bentonite. Like a decrease in the thickness of an ash bed and in the size of its constituent fragments away from the source, the decrease in amount of these crystalline particles is an index of distance from the volcanic vent, as shown by the ash erupted from Krakatoa. ${ }^{16}$

A fourth factor in the varying hardness of the Mowry shale appears to be the degree of weathering; the light-colored weathered chips seem to be more siliceous and brittle than the fresh rock. Silicification of exposed rock surfaces is said to be widespread and especially noticeable in the more arid climates. In the Black Hills region the writer has found evidence that the Minnelusa and Lakota sandstones, the Greenhorn limestone, and old terrace deposits have commonly undergone hardening of this type. Silicification at the outcrop has been explained as due to evaporation and secondary deposition of silica originally present in the rock and to concentration at the surface by leaching out of other constituents. ${ }^{17}$ However, well cuttings show that the Mowry is harder than other Cretaceous shales even far underground, and it appears certain that the greater part of the silicification is unrelated to weathering.

A fifth but less definite observation is that the Mowry shale is hardest in its finest-grained portions. This generalization may not be valid, for differences in the size of grain of the Mowry shale are difficult to recognize in the field, and the somewhat softer, coarser beds were found well below the top of the member, where the finer-grained beds are also softer.

${ }^{36}$ Murray, John, and Renard, A., On the microscopic characters of volcanic ashes and cosmic dust and their distribution in the deep-sen deposits: Roy. Soc. Edin burgh Proc., vol. 12, p. 486, 1884.

" T Twenhofel, W. H., Treatise on sedimentation, p. 387, 1926. 
It has been found that some shale formations are hardest where they are most folded or otherwise affected by regional metamorphism. ${ }^{18}$ This possible factor was in mind during the field work, but no evidence indicating a relation of this sort was noted.

\section{INFERENCES FROM FIELD RELATIONS AS TO ORIGIN OF SILICA IN MOWRY SHALE}

The field observations thus show that the Mowry shale hardens progressively upward to its upper boundary and toward associated bentonite beds, also westward toward the probable source of the sediments in one of the associated bentonite beds; it probably hardens somewhat with weathering and increasing fineness of the shale. These relations suggest several possible explanations of the hardness or silica content and of other peculiarities of the Mowry shale.

The stratigraphic and geographic variations in hardness of the Mowry shale in the Black Hills region and confirmatory evidence in younger beds in the same region indicate strongly a relation to the occurrence of bentonite. The theory, suggested by Hewett, ${ }^{19}$ that bentonite is an altered volcanic ash has been firmly established by the investigation of others. Ross and Shannon, who have studied bentonite exhaustively, recently defined it as "a rock composed essentially of a crystalline claylike mineral formed by devitrification and the accompanying chemical alteration of glassy igneous material, usually a tuff or volcanic ash." ${ }^{20}$ In addition to these conclusions regarding bentonite in general, definite evidence of this origin is presented by the bentonite beds of the Black Hills region.

The field relations of the hardness of the shale to occurrences of bentonite first suggested to the writer that the Mowry shale may have been secondarily silicified by solutions derived from the bentonite. However, this hypothesis encounters many objections, and the relation can be explained by the presence of similar original material in both the bentonite and the harder shale. That is, the relation might be either original or secondary: the Mowry shale and the associated bentonites might be derived from a common source, or the Mowry may have been secondarily silicified. These possibilities will be discussed more fully after a consideration of the chemical and microscopic evidence.

It is possible that the relation of hardness to bentonite is merely fortuitous and that the hardness increases

\footnotetext{
18 Arnold, Ralph, and Anderson, Robert, Geology and oil resources of the Santa, Maria oil district, Calif.: U. S. Geol. Survey Bull. 322, p. 46, 1907. Wilson, J. H. Lithologic character of shale as an index of metamorphism: Am. Assoc. Petroleum Geologists Bull., vol. 10, pp. 625-633, 1926. Russell, W. L., Porosity and crushing strength as indices of regional alteration: Idern, pp. 939-952

${ }^{10}$ Hewett, D. F., The origin of hentonite: Washington Acad. Sci. Jour., vol. 7, pp. 196-198. 1917.

${ }^{20}$ Ross, C. S., and Shannon, E. V., The minerals of bentonite and related clays and their physical properties: Am. Ceramic Soc. Jour., vol. 9, p. 79, 1926.
}

upward and westward as a result of lithologic variations only accidentally connected with occurrences of bentonite. One of the field relations suggests that size of grain may be the lithologic variation that causes variations in hardness. On this assumption the harder and finer-grained portions of the shale may have originally contained more silica (either finely divided clastic quartz or colloidal silica) than the coarser-grained portions, or precipitation of secondary silica may have been greater in the fine shale owing either to the capillary size of pore spaces or to the presence of substances that coagulate silica. However, other considerations make this hypothesis appear improbable. No evidence of progressive coarsening downward was observed, and in fact the clay in the Nefsy member appears finer than much of the Mowry. The hypothesis would call for a coarsening of the sediments after each ash fall, whereas finer sediments might more logically be expected. Moreover, the Mowry shale of the Black Hills does not appear to coarsen southeastward, as required by the hypothesis, and in Montana the sandiness is reported to increase westward.

The possibility that silicification resulted from the replacement of rock of some other type, such as a silty limestone, may be mentioned, but the absence elsewhere of any readily replaceable rock at this horizon and of replacement phenomena in the Mowry itself makes this method of silicification seem very improbable.

The abundance of fish scales, the relative scarcity of shells and bones, and the presence of volcanic ash and Radiolaria suggest as another possibility that the Mowry may be the result of extremely slow sedimentation, for teeth and other chemically resistant bony remains of fish are widespread, and volcanic ash and Radiolaria are common in several types of deep-sea deposits. ${ }^{21}$ The known paleogeography at the time of deposition of the Mowry shale and the great thickness of the Aspen formation make it appear extremely improbable that the Mowry accumulated in abyssal depths, like the deposits described in the Challenger reports, but it is conceivable that comparable conditions of slow sedimentation may have existed at times in the center of the shallow Cretaceous sea of the Western Interior.

\section{CHEMICAL COMPOSITION OF MOWRY SHALE AND RELATED DEPOSITS}

Some of the analyses made by the chemists of the United States Geological Survey for the writer's forthcoming general report upon the Cretaceous and Eocene rocks on the northwest flank of the Black Hills have a bearing upon the origin of the Mowry shale.

\footnotetext{
${ }_{21}$ Murray, John, and Renard, A. F., Challenger Rept., Deep-sea deposits, 1891.
} 
Chemical analyses of Mowry shale and other rocks

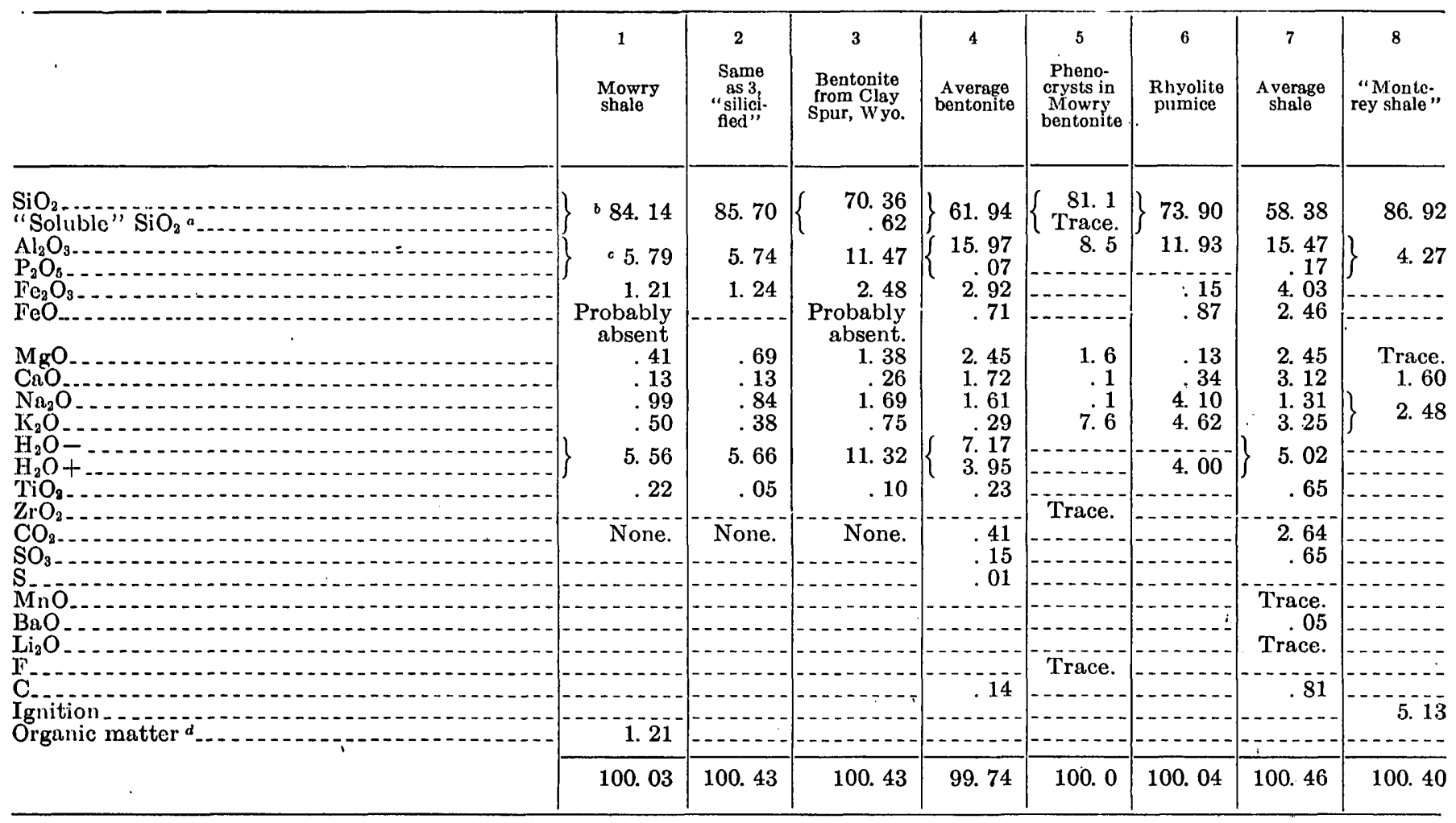

- By 5 per cent $\mathrm{Na}_{2} \mathrm{CO}_{3}$ solution.

列

1. Weathered Mowry shale, sample collected by W. W. Rubey from upper part of member in sec. 7, T. 48 N., R. 65 W., near Thornton, Wyo. J. G. Fairchild, analyst.

2. Same as No. 3, "silicified" by arbitrarily increasing the proportion of silica so that the other constituents are diluted to just one-half.

3. Bentonite, complete sample collected by W. W. Rubey from quarry at Clay Spur, sec. 30, T. 47 N., R. 63 W., Wyo. J. G. Fairchild, analyst.

4. Average of seven bentonite samples. Spence, H. S., Bentonite, p. 14, Canada Dept. Mines, Mines Branch, 1924.

5. Phenocrysts in bentonite beds associated with Mowry shale, computed from microscopic data.

6. Rhyolite pumice from Sailles, Mont Doré, France. Washington, H. S., Chemical analyses of igneous rocks: U. S. Geol. Survey Prof. Paper 99, p. 129, 1917.

7. Average analysis of 78 shales. Clarke, F. W., The data of geochemistry, 5th ed.: U. S. Geol. Survey Bull. 770, p. $631,1924$.

U. S. Geol. Survey Bull. 322, p. $45,1907$.

\section{EXCESSIVE AMOUNT OF SILICA IN MOWRY SHALE}

Comparison of an analysis of Mowry shale from a locality near Thornton, Wyo., with the average analysis of 78 shales ${ }^{22}$ shows the Mowry to be exceptionally high in silica and low in the other constituents, especially ferrous iron and carbonates. (See Nos. 1 and 7 in table of analyses.) The excess of silica is striking, for even on the assumption that silicate minerals with the highest probable silica ratios are present (orthoclase, albite, montmorillonite, ${ }^{23}$ and knolin) computing the norms shows that at least 70 per cent of the rock is uncombined silica.

The high silica content of the Mowry shale may be explained by the presence of large amounts either of clastic silica or of silica that was chemically precipi-

\footnotetext{
23 Clarko, F. W., The data of geochemistry, 5th ed.: U. S: Geol. Survey Bull. 770, p. 631,1924

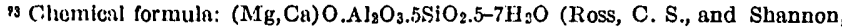
E. V., op. cit., pp. 87-89).
}

tated at the time of deposition of the rock or else later. Other facts also have suggested the possibility that the peculiar composition of the Mowry shale may be due to chemical precipitation of silica either at the time of deposition or later. Precipitation of such unusual amounts might be explained by an exceptional source of silica or by the presence of unusually effective coagulating agents in the shale or in waters at one time in contact with the shale, or these factors may have been jointly effective. An exceptional source of silica might be unusual amounts of it in the original sea water or in circulating ground waters. Such unusual amounts might be accounted for by any one of several suppositions, the relative probability of which can be most effectively considered after a discussion of the microscopic evidence. Chemical analyses in themselves throw light on the possible presence of coagulating agents. 


\section{POSSIBLE PRECIPITANTS OF SILICA}

If some substances that are especially effective in coagulating dissolved or colloidally suspended silica are found to be unusually abundiant in the Mowry shale, the hypothesis of primary or secondary precipitation of silica will be strengthened. Substances likely to be present that are considered especially effective in precipitating silica are ammonium carbonate, ${ }^{24}$ phosphates, ${ }^{25}$ ferric oxides ${ }^{25}$ bicarbonates ${ }^{26}$ in uncommonly siliceous waters, ${ }^{27}$ and ions of lime and magnesia. ${ }^{28}$

The widespread occurrence of fish scales and bone fragments in the Mowry shale suggests that phosphates may have precipitated the silica. However, an analysis shows only 0.40 per cent of $\mathrm{P}_{2} \mathrm{O}_{5}$ in a sample of hard scale-bearing Mowry shale, which is practically the same amount as the 0.42 per cent found in a fragment of Belle Fourche shale chosen for comparison. The analysis of the Mowry shale (No. 1 in the table) shows that none of the other substances favorable to precipitation are unusually abundant. However, the sample contains a rather linge proportion of organic matter (1.21 per cent by weight), and another specimen, from sec. 35, T. 57 N., R. 66 W., Crook County., Wyo., analyzed by the United States Bureau of Mines, contained 1.40 per cent of organic carbon, 0.14 per cent of organic hydrogen, and 0.05 per cent of nitrogen. The dark color suggests that a large part of the shale would contain even more organic matter. During the decay of this organic material carbon, dioxide (and hence, in sea water, calcium and magnesium bicarbonates) and ammonium carbonate ${ }^{29}$ were almost certainly abundant, and these compounds may have precipitated the silica at that time. Thus, before its complete burial, the Mowry shale, or rather the waters in contact with it, probably contained adequate coagulating agents.

One alternative supposition is that the precipitating agents were contained in later infiltrating ground water. On this assumption both the excess silica and the precipitant must have been brought in by ground water, and it is necessary to postulate a mixing of the two solutions. Even assuming that water could circulate freely through such fine and impermeable material, it would be difficult to explain why an interaction of this sort would be restricted to the horizon of the Mowry shale over so great an area. As this hypothesis of the mixture of two ground waters

24 Davis, E. F., The radiolarian cherts of the Franciscan group: California Univ Dept. Geology Bull., vol. 11, pp. 399-402, 1918. Ammonium carbonate is also commonly used in laboratories to precipitate dissolved silica.

${ }_{25}$ Wallace, R. C., The distribution of the colloidal products of rock weathering: Roy. Soc. Canada Proc. and Trans., 3d ser., vol. 17, sec. 4, p. 73, 1923.

${ }_{20} \mathrm{Cox}, \mathrm{H}, \mathrm{Pan}, \mathrm{R}, \mathrm{S}$, and Gottschalk, V. H., Studies on the origin of Mis souri cherts and zinc ores: Missouri Univ. School of Mines and Metallurgy Bull. vol. 3, No. 2, pp. 7-12, 1916.

${ }^{27}$ Lovering, T. S., The leaching of iron protores; solution and precipitation of silica in cold water: Econ. Geology, vol. 18, pp. 537-538, 1923.

${ }_{28}$ Tarr, W. A., Origin of the chert in the Burlington limestone: Am. Jour. Sci. 4th ser., vol. 44, p. 436,1917

so Clarke, F. W., op. cit., pp. 123, 149. fails to account for the general and detailed association of the Mowry lithology with bentonite and as it also encounters other serious objections if carried further, it may be dismissed from consideration.

It is possible, however, that the silica may have been precipitated from exceptionally siliceous ground water by conditions of temperature or pressure in the shale rather than by the presence of precipitants. Another hypothesis of this physico-chemical type is that detrital grains undergoing compacting might go into solution at their points of contact and that silica might be precipitated in adjacent pore spaces. ${ }^{30}$

\section{"SOLUBLE" SILICA}

A further test of the general hypothesis of chemical precipitation, either primary or secondary, may be made by a determination of the percentage of "soluble" or amorphous silica now present in the rock. The occurrence of a considerable amount would strengthen the hypothesis, but its absence would have little significance, for, even though originally precipitated as a gel, the silica might have crystallized into the less soluble quartz or chalcedony.

This test yielded no conclusive evidence, for a typical sample of Mowry shale contained 0.73 per cent of "soluble" silica, and a sample of Belle Fourche shale, chosen for comparison, 0.70 per cent.

\section{COMPOSITION OF ASSOCIATED BENTONITE}

The field observations suggest that the excess silica in the Mowry shale is somehow related to associated bentonite beds. Chemical analyses bear out this suggestion, for a sample of the bentonite bed at the top of the Mowry, collected from the bentonite quarry at Clay Spur, Wyo., contains, like the shale itself, an unusually high percentage of silica (70.98 per cent; see analyses 3 and 4). This is not only far higher than the 53.50 per cent in a bentonite bed in the soft Belle Fourche shale, about 20 feet above the Mowry, sampled near by, but is also higher than the percentage in any of the 35 or 40 published analyses of bentonite seen by the writer.

A published analysis ${ }^{31}$ of a bentonite said to have been collected in sec. 30, T. 47 N., R. 63 W., Wyo. (the same locality as the Clay Spur quarry), shows but 54.31 per cent of silica. Mr. Hewett, to whom the sample was sent for study and comparison with other Wyoming bentonites, informed the writer that this analysis represents the finer 92 per cent of the sample as separated by mechanical analysis. A new determination shows the gross sample to contain 57.1 per cent of silica. This is 14 per cent less than was

${ }^{30}$ Johnston, John, and Adams, L. H., On the effect of high pressures on the physical and chemical behavior of solids: $\Lambda \mathrm{m}$. Jour. Sci., 4th ser., vol. 35, pp. 211, 215-217, 1913. Johnston, John, and Niggli, Paul, The general principles underlying metamorphic processes: Jour. Geology, vol. 21, pp. 499, 608-613, 1913.

31 Hewett, D. F., Geology and oil and coal resources of the Oregon Basin, Mee. teetse, and Grass Creek Basin quadrangles, Wyo.: U. S. Geol. Survey Prof. Paper 145 , p. 56,1926 


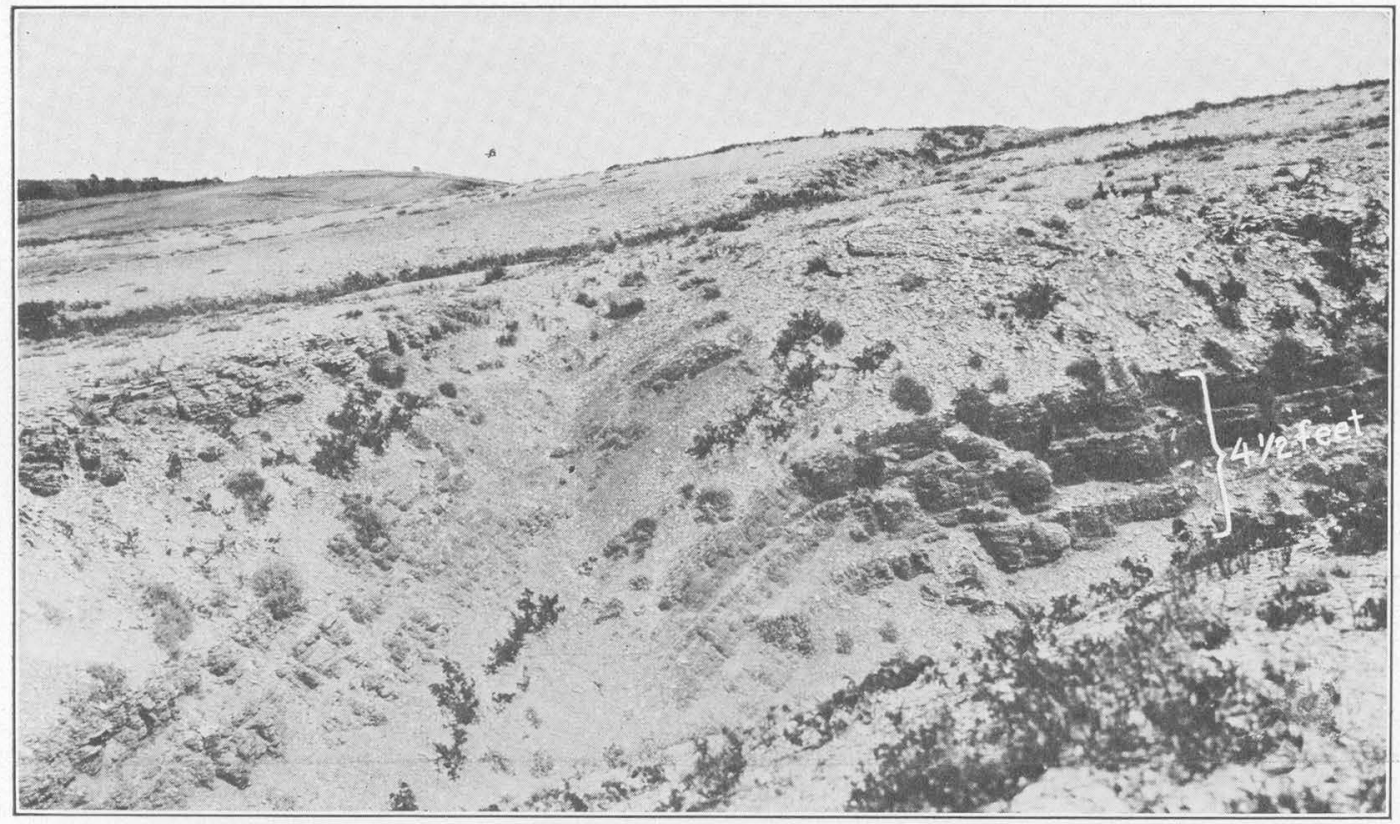

A. OUTCROP OF MOWRY SHALE ON THORNTON DOME, IN SEC. 7, T. 48 N., R. 65 W., WESTON COUNTY, WYOMING

Shows a small reverse fault; typical thin bedding of shale and alternation with thin beds of bentonite; and characteristic bare chip-covered ground. This outcrop differs from most others in not being heavily overgrown with pines

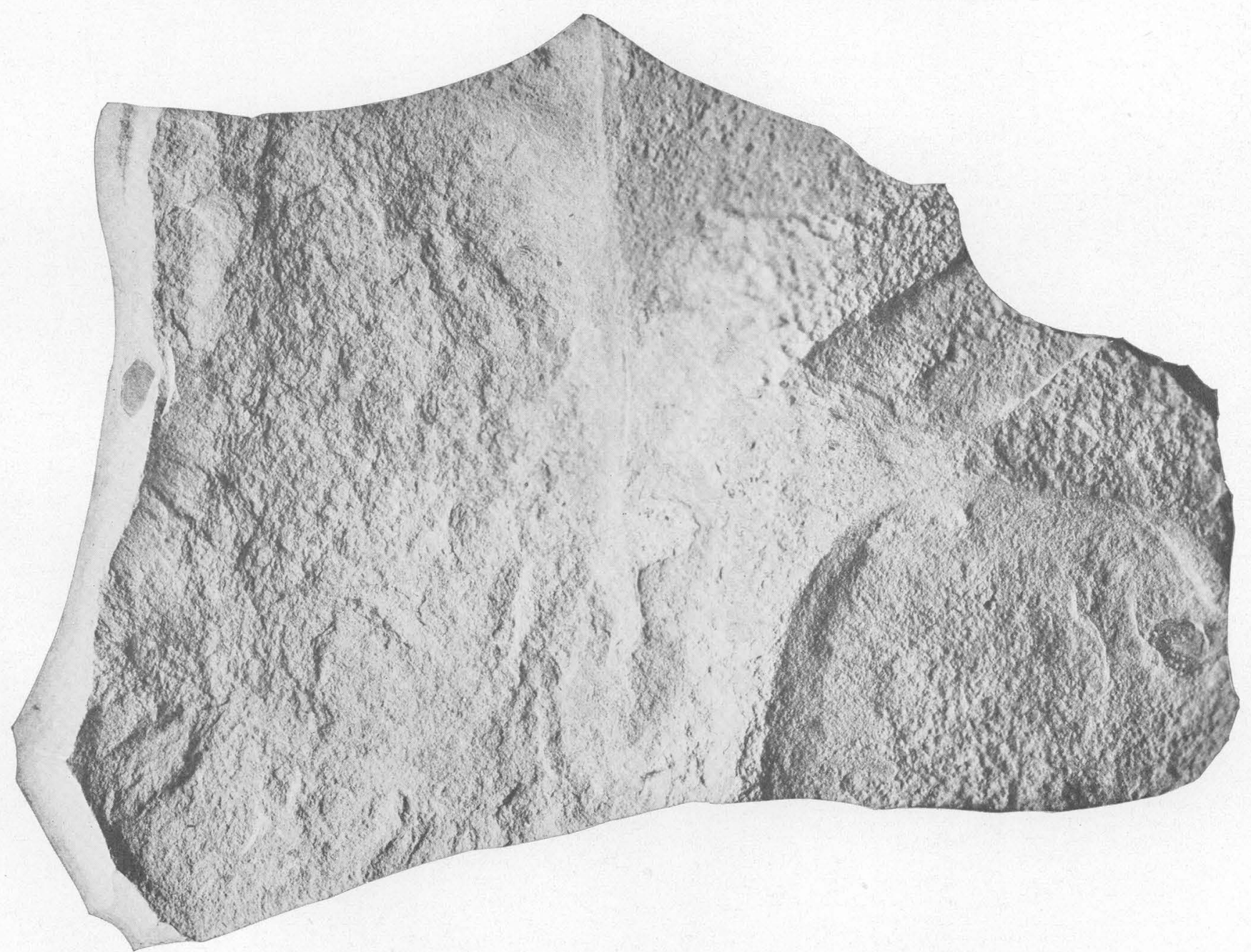

B. HAND SPECIMEN OF MOWRY SHALE COLLEGTED NEAR NEWCASTLE, WESTON COUNTY, WYOMING, IN SEC. 25 , T. 45 N., R. 62 W. Shows typical distribution of fish scales and subconchoidal fracture. Natural size 

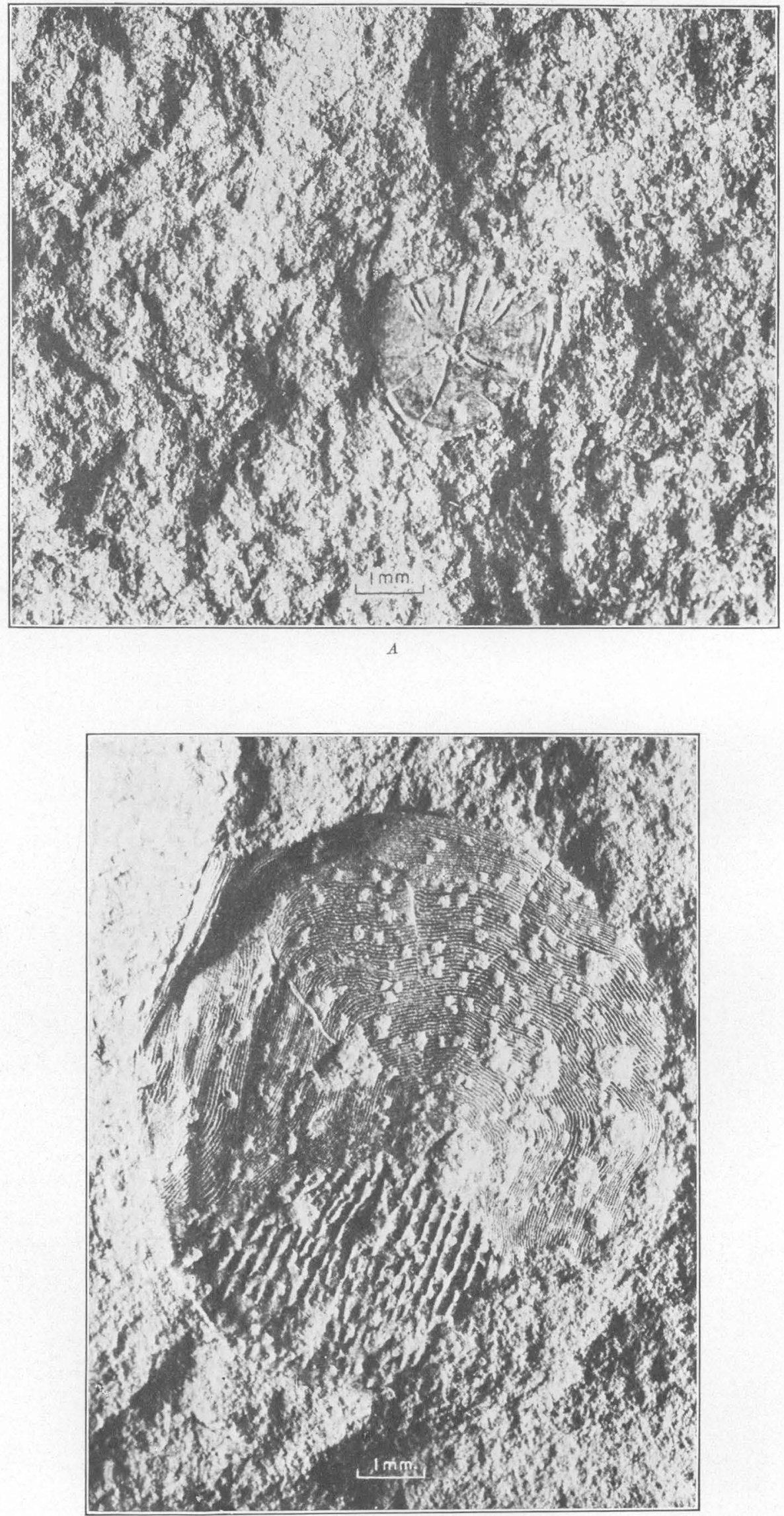

$B$

FISH SCALES IN MOWRY SHALE FROM SEC. 25, T. 45 N., R. 62 W., WYOMING 


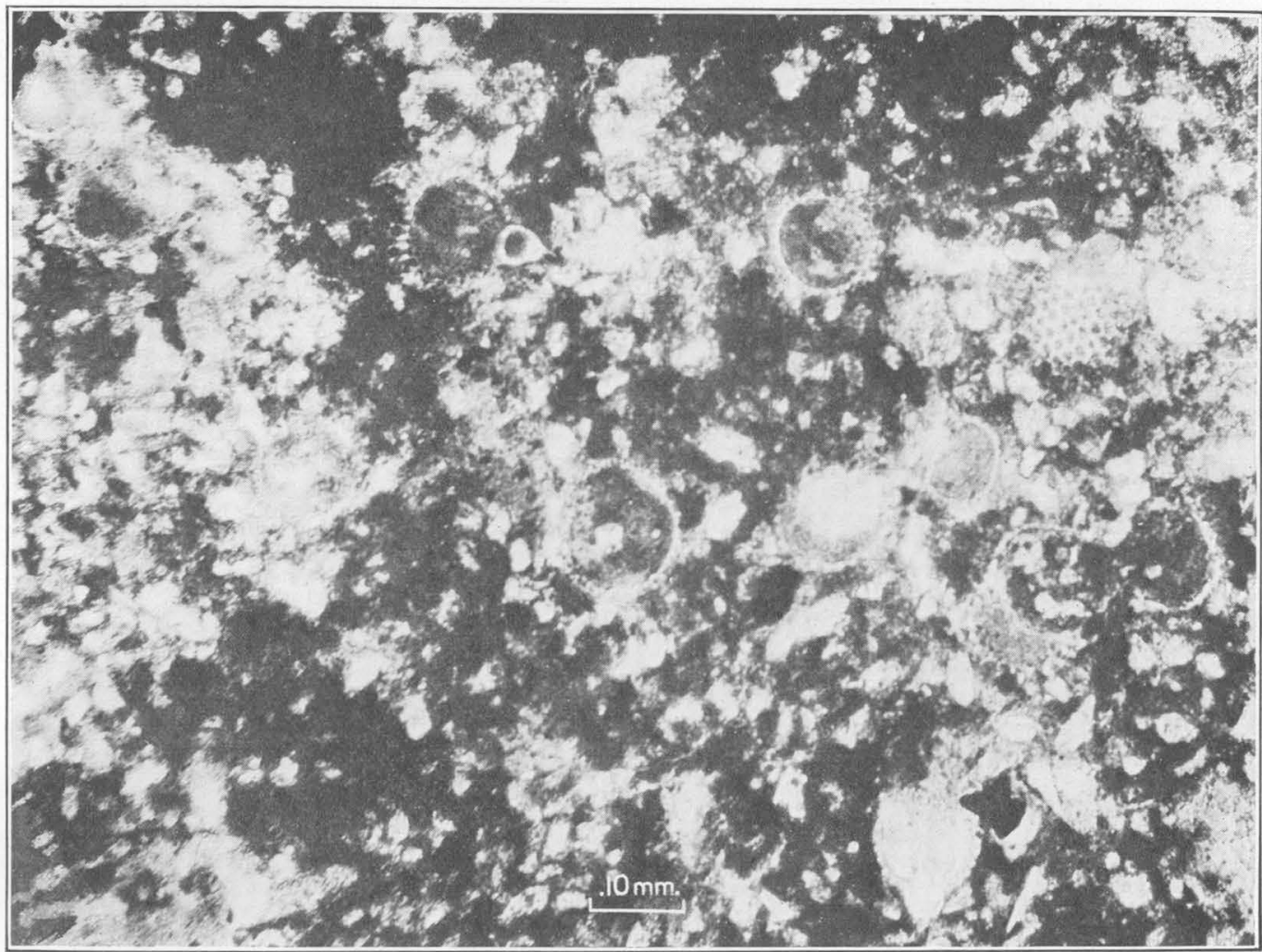

A. THIN SECTION OF MOWRY SHALE FROM SEC. 35, T. 57 N., R. 66 W., CROOK COUNTY, WYOMING Shows an exceptionally large number of Radiolaria

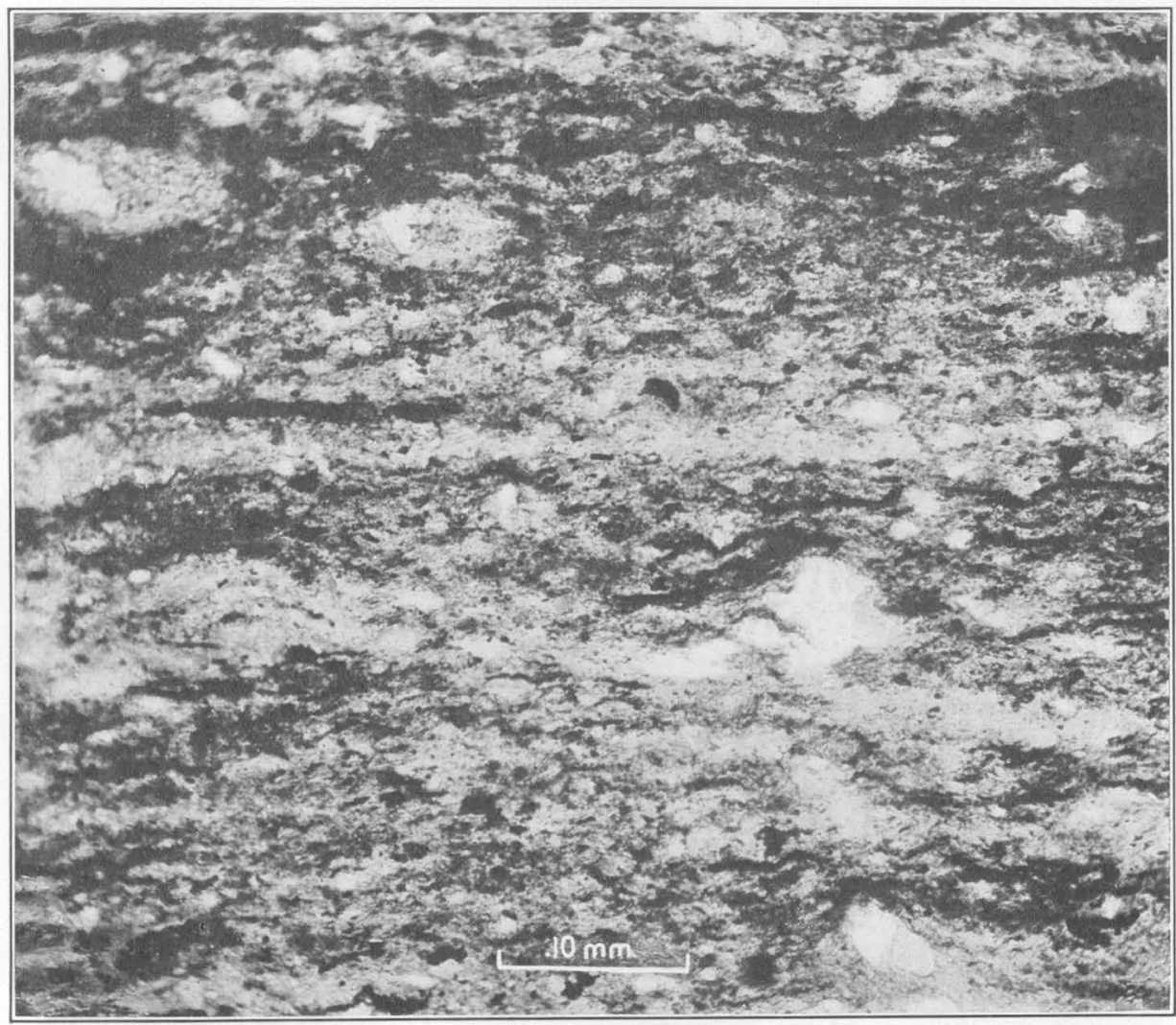

B. THIN SECTION OF MOWRY SHALE FROM THORNTON DOME, WESTON COUNTY, WYOMING

The larger masses, unusually abundant in this section, are remnants of partly crystallized opal or glass 
found in the writer's sample from the Clay Spur quarry. It is, of course, possible that a bed of bentonite 4 feet thick may vary this much in chemical compo-. sition from one layer to another, but the lithology of the hand specimen and comparison of the silica content and the relative proportion of other constituents with other analyses make it seem more probable that the earlier sample was collected from a higher bed that crops out near the present Clay Spur quarry or from a quarry in another bed 12 miles distant.

The high silica content of the writer's sample of the bentonite from the Clay Spur quarry suggests that much detrital quartz may be present as an impurity, but other facts make this seem very improbable. This sample contained only 0.2 per cent of grains coarser than 0.07 millimeter in diameter (sand-sized particles of calcite, iron oxide, and clay aggregates being discarded). This is considerably less than the average percentage of grains larger than 0.07 millimeter found in 30 other samples of bentonite from the Black Hills of which the writer made mechanical analyses. Microscopic examination of the coarser particles revealed little obviously detrital material in any.of the 30 samples. In the Clay Spur sample the largest grains were 0.25 millimeter in diameter, well above the lower limit of rounding, yet no evidence of abrasion indicating admixed detrital grains was noted. Furthermore, this coarser 0.2 per cent consisted largely of aluminum silicates (feldspar) rather than pure silica (quartz). That is to say, this unusually siliceous bentonite contains less than an average amount of sand-sized particles which might possibly be detrital, the few coarser grains which are present show no evidence of being other than phenocrysts, and they are not much more siliceous than the complete sample. These facts lead to the conclusion that the excess silica in this sample is present not as coarse detrital quartz but as very finely divided material. Small quantities of very finely divided or clay-sized quartz particles are doubtless formed by several natural agencies, but, considering the lower limits of abrasion and the ready solubility of the smallest fragments, ${ }^{32}$ a large proportion of claysized clastic quartz grains in any rock would demand some very unusual geologic process of disintegration.

This evidence that the silica in the bentonite is very finely divided suggests that it may be a chemical or colloidal precipitate which was formed either during or after deposition of the ash. It seems improbable that silicification was later than deposition, for if the bentonite were thus secondarily silicified, its ability to swell when wetted would probably be considerably reduced. ${ }^{33}$ However, of about 35 samples of bentonite from the Black Hills disintegrated by the writer, the Clay Spur sample was one of three that swelled

\footnotetext{
s Galloway, J. J., The rounding of grains of sand by solution: Am. Jour. Sci., 4th ser., vol. 47, pp. 270-280, 1918.

83 Ross, C. S., personal communication.
}

most. Therefore it seems probable that the silica in the bentonite is an original chemical constituent of its finer portion. From this conclusion, the close association of the two rocks, and the similarity of their silica content, theinference could bedrawn that the silica in the Mowry shale was likewise probably an original chemical constituent. This possibility will be considered more fully in the light of additional evidence.

Not only are the analyses of the two rocks similar in their high content of silica, but the relative proportions of the other compounds present are almost identical. By adding to the bentonite at Clay Spur an amount of silica equal to the total weight of the sample (that is, more than doubling the $\mathrm{SiO}_{2}$ so that the other constituents are diluted to just one-half) the two analyses become strikingly similar. All the constituents except silica and organic matter are then within 0.3 per cent of the same in the two analyses, and the average difference, about 0.1 per cent, is only slightly greater than the probable error of the determinations. (See analyses 1 and 2.) This remarkable similarity between the two analyses suggests that the Mowry shale may be a silicified bentonite. Although the organic matter, structure, and other characteristics of the Mowry do not bear out this suggestion, there is a strong indication that the Mowry shale consists of approximately equal proportions of free silica and of the same material that altered into bentonite.

Another possible explanation of the similarity of the two analyses is that the silica content of the ash varied from time to time and that the more siliceous ash became a hard shale and the more normal ash altered to bentonite. Ross and Shannon think it "quite probable that glasses very high in silica are fairly stable and do not readily alter to bentonite." ${ }^{34}$ However, no volcanic rocks of which analyses are available have a composition very similar to that of the Mowry shale analyzed, and the explanation calls for an utterly improbable repeated alternation in the percentage of one constituent in the original ash deposited. I.t seems much more probable, in view of the analyses, that any ash deposited in the Mowry shale had approximately the same composition as that in the associated bentonite beds.

The composition of the water in which the ash fell might have a strong influence on the type of decomposition and the resulting rock, but the sudden and repeated changes in composition of the water demanded in order thus to explain the differences between the Mowry shale and the bentonite seem quite as improbable as repeated changes in the silica content of the original ash.

A further possibility is suggested by the observation of Murray and Renard ${ }^{35}$ that because of the order

34 Ross, C. S., and Shannon, E. V., op. cit., p. 84.

${ }_{35}$ Murray, John, and Renard, A., On the microscopic characters of volcanic ashes and cosmic dust and their distribution in the deep-sen deposits: Roy. Soc. Edinburgh Proc., vol. 12, p. 487, 1884 . 
of crystallization in a magma and the differences in specific gravity of the minerals, ash tends "to become more acid [siliceous] the farther it is removed from the center of eruption." That is, the minerals that crystallize first in a cooling magma are heavier and less siliceous than the magma itself, and in a volcanic eruption these minerals would fall nearest the source, leaving the uncrystallized and more siliceous portion to travel farther. Thus ash erupted over a long period of time might maintain the same composition at the volcanic vent, but variations in intensity of the explosions might cause variation in the composition of the ash deposited at any one distant point. However, this factor would not be effective in increasing the silica content of an ash after the heavier minerals had settled out, and, as the bentonite associated with the Mowry shale is in itself unusually siliceous, the extra silica in the Mowry shale is probably best explained by other means.

Silicification of the Mowry shale by the bentonite has been suggested by both field and chemical evidence. Ordinary bentonite contains a somewhat lower percentage of silica than the ash from which it was derived, ${ }^{36}$ thus indicating that silica was given off during the alteration. Also the readiness with which particles of bentonite pass into an all but permanent suspension in water suggests that ground water might transport such material freely. However, this hypothesis calls for a free access of ground water to the bentonite, a difficult feat because of the intense swelling of bentonite when wetted. This supposition also makes it difficult to explain why the shale near all bentonite beds is not hardened. Furthermore, quantitative considerations greatly lessen the probability of this mode of origin of the silica in the Mowry. Although bentonite seems to be more abundant in the upper part of the Mowry shale than elsewhere throughout the Cretaceous rocks of northeastern Wyoming, it does not commonly constitute more than 10 per cent of the section, even in the upper 50 feet of that member. From the estimates of the silica content of the Mowry near Thornton, Wyo., it seems that the upper 50 feet contains about 20 per cent more silica than the adjacent softer shales, and hence the hypothesis demands that the bentonite beds furnish to the Mowry shale an amount of silica that is twice their own volume-that is, about twenty times as much silica as they would be expected to give off. It may be concluded, therefore, that bentonite is not an adequate source of all the excess silica in the Mowry shale.

On the other hand, the small portion of silica that causes local hardening near bentonite beds might conceivably be explained in this manner. Evidence indicating that in some places the alteration of ash to

${ }^{36}$ Ross, C. S., and Shannon, E. V., op. cit., pp. 88-89. Ross, C. S., personal communication. bentonite occurred after burial is cited in the conclusion to this paper, and, if this is true of the Mowry bentonites, siliceous water from the altering ash might have affected the underlying shale beds. However, the hypothesis seems unlikely in view of the close similarity between the decrease in hardness downward from any one bentonite bed and the decrease downward through the entire thickness of the Mowry shale, where as previously stated, the process seems quantitatively inadequate. Also the exceptionally high silica content of the bentonite certainly suggests that large quantities of silica can not have been leached from it. Furthermore, if local hardening of the Mowry shale near bentonite is caused by descending ground water, other Cretaceous bentonites in the same region should likewise be underlain by siliceous shale, whereas all other examples of hardened shale noted in the Black Hills region lie above instead of below the bentonite beds.

\section{COMPOSITION OF ORIGINAL ASH}

The conclusion that the Mowry shale consists in large part of the same material as that which altered into the bentonite makes it pertinent to consider the probable composition of the ash that formed the bentonite. In an examination of the sand-sized particles in bentonites from the Black Hills region, the writer estimated the proportions of different minerals present. An average of the counts of grains coarser than 0.07 millimeters in 21 samples of bentonite associated with the Mowry shale, after discarding clay aggregates, gypsum, iron oxides, and calcite, is as follows:

\begin{tabular}{|c|c|}
\hline Quartz $\ldots \ldots$ & $\begin{array}{r}\text { Por cent. } \\
55\end{array}$ \\
\hline Orthoclase and sanidine & 35 \\
\hline Biotite & 8 \\
\hline Plagioclase $\left(\mathrm{An}_{35-40}\right) \ldots$ & \\
\hline Zircon & Trace. \\
\hline Glass_ & Trace. \\
\hline Opal & Trace. \\
\hline Apatite. $\ldots$ & Trace. \\
\hline
\end{tabular}

On the assumption that these fragments are phenocrysts, their mineralogic content indicates that the igneous rock in which they crystallized had the composition of a rhyolite that was very high in silica and low in plagioclase. In some of the samples a few rounded sand grains were noted, and these detrital grains make the average composition of the supposed igneous rock somewhat too high in quartz and, perhaps, in potash feldspars. If the figures given above are computed by norms into the form of a chemical analysis, it is seen that with the exception of the high percentage of $\mathrm{K}_{2} \mathrm{O}$ the composition of the sand-sized material is similar to that of the Mowry shale and the bentonite at Clay Spur. (See analyses 5, 1, and 3.) Considering the facts that bentonite contains a somewhat lower percentage of silica than the ash from which it was derived and that the sand-sized particles in bentonite 
probably contain some detrital quartz, it is reasonable to assume that the original ash had a silica content intermediate between that of the bentonite and that of the sand-sized particles. The same relation should also hold for several other constituents.

The more acidic or siliceous varieties of rhyolite and other igneous rocks of similar composition contain from 70 to 80 per cent of $\mathrm{SiO}_{2}$ and commonly from 1 to 7 per cent each of $\mathrm{Na}_{2} \mathrm{O}$ and $\mathrm{K}_{2} \mathrm{O}$. An analysis that is fairly typical (though somewhat low in $\mathrm{Fe}_{2} \mathrm{O}_{3}$ and $\mathrm{CaO}$ ) is that of a rhyolite pumice from Sailles, Mont Doré, France (analysis 6). Comparison of the analyses of acidic rhyolites, the phenocrysts in Mowry bentonites, the bentonite at Clay Spur, and the Mowry shale indicates that the most soluble constituents, the alkalies, have been largely removed from the bentonite and shale. The conclusion therefore seems warranted that the original ash in the bentonite at Clay Spur and in the Mowry shale was of acidic composition and that during its alteration the alkalies were largely removed by solution.

\section{SUMMARY OF CHEMICAL EVIDENCE}

Analyses show that the Mowry shale contains an exceptionally large amount of uncombined silica. Consideration of chemical evidence leads to the conclusion that this silica may have been precipitated contemporaneously by the decay of organic matter or by substances in the sea water, it may have been deposited later during consolidation, or it may possibly be original very finely divided clastic material. It seems unlikely that the excess silica in the shale came from the bentonite. The composition of the Mowry shale and that of the associated bentonite are remarkably similar in the high percentage of silica and the relative proportions of the other constituents, strongly indicating that both contained the same original material. Analyses and phenocrysts in the bentonite indicate that this original material in both the bentonite and the shale was an acidic or siliceous ash from which the alkalies have been largely removed by solution.

\section{MICROSCOPIC CHARACTERISTICS OF MOWRY SHALE}

The Mowry shale is so fine grained and dark colored that microscopic study yields unsatisfactory results, yet mu,ch important evidence can be obtained in no other way. Both thin sections and crushed powders immersed in liquids of known refractive index were examined.

\section{MATERIAL}

Most of the thin sections of Mowry shale that were studied consist chiefly of clay-sized material. All but one of the Black Hills specimens contain less than 5 per cent of grains larger than about 0.005 millimeter in diameter (approximately the limiting diameter between silt and clay ${ }^{37}$ ). The coarser sample contains somewhat more than 50 per cent of these sand-sized and silt-sized grains. In every specimen the largest particle noted was between 0.15 and 0.20 millimeter across. "The largest grains in the bentonites associated with the Mowry shale have diameters of 0.2 to 0.7 millimeter. The coarser material in the shale consists of angular grains of quartz, some fresh orthoclase and sanidine, and amorphous and finely crystalline particles. The finely crystalline particles include round and irregularly shaped masses of cryptocrystalline quartz and remnants of partly crystallized silica or glass that distort the bedding. (See pl. 16, B.) A few cuspate fragments of faintly brownish glass were recognized.

The fine portion is largely cryptocrystalline but contains some amorphous substances and appreciable amounts of very finely divided crystalline material, most of which is oriented essentially parallel to the bedding and shows a marked positive elongation (that is, the faster optic axis is approximately at right angles to the elongation of the particles). This fine crystalline material consists chiefly of quartz and an unknown clay mineral but contains also some potash feldspar, chalcedony, and biotite. In its birefringence, refractive indices, structure, and mode of occurrence ${ }^{38}$ the clay mineral resembles montmorillonite, the common mineral of bentonite. The cryptocrystalline material appears from its indices of refraction to be chiefly quartz, with which are mixed organic matter and the clay mineral, but a large amount has refractive indices ranging between 1.51 and 1.545, and a little (very probably opal) has an index lower than 1.47. All stages in a complete gradation between the apparently amorphous material of low index and the cryptocrystalline aggregates of higher index may be found. A few apparently residual amorphous masses were seen. In some of the thin sections layers of cryptocrystalline quartz and some opal alternate with the more argillaceous material in very thin laminae. No evidence of secondary deposition such as veinlets or filled cavities was found.

A large amount of dark organic matter is present in all the specimens. It consists chiefly of small opaque fragments but contains also a few large transparent amber-colored masses of optically inactive material. The opaque organic matter is thoroughly disintegrated, and no plant or animal structure is visible. In many sections distinct, very thin bedding planes about 0.1 millimeter apart are marked by the organic matter. Some grains of iron oxide are also present.

\section{NATURE OF FINE-GRAINED MATERIAL}

The complete gradation between the cryptocrystalline material common in the groundmass and the

37 Wentworth, C. K., A scale of grade and class terms for clastic sediments: Jour. Geology, vol. 30, pp. 377-392, 1922.

s8 Ross, C. S., personal communication. 
amorphous material indicates that the former was derived from the latter. At least a part of the original amorphous material is opaline silica, but the analyses show pretty conclusively that most of it was of a more complex chemical composition. This complex original material may have been an isotropic colloid, but several lines of evidence indicate that a large amount of it may have been volcanic glass. Nearly all of the amorphous and cryptocrystalline material has refractive indices ranging between that of quartz and that of a glass with the composition of granite (1.51), ${ }^{39}$ thus suggesting that the original substance from which the present material was derived was an acidic glass with a refractive index of about 1.51 , rather than opal, which has an index of 1.46 or less. The small amounts of sodium and calcium shown in the analysis are not accounted for by the minerals recognized among the coarser grains (no plagioclase having been detected), thus indicating that these two elements are present in the finer portion, perhaps as an acidic volcanic glass. The clay mineral is similar to that characteristic of bentonite. It is true that only a few shards of glass were recognized and that those were among the coarser grains, but the glass in the associated bentonite has also lost these characteristic forms. The most definite evidence bearing on the identification of the amorphous matter as glass rather than opal is the fact that analyses, discussed elsewhere in this paper, show that the Mowry shale contains less than 1 per cent of opaline silica.

\section{RELATIVE ABUNDANCE OF CONSTITUENTS}

From the microscopic evidence and computations based on the chemical analyses, it is possible to make an approximate estimate of the constitution of a typical sample of Mowry shale of the Black Hills region. If Van Hise's definition of chert ${ }^{40}$ as including "all forms of finely crystalline nonfragmental silica, including opaline, semicrystalline, and completely crystalline varieties," is adopted for the fine-grained silica in the Mowry shale the composition of a typical sample would be roughly as follows:

Very fine-grained sand and silt, chiefly quartz .........

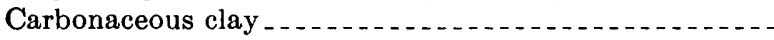

Chert . . . . . . .

More or less devitrified volcanic glass (?)

Iron oxide.

SAMPLES OF MOWRY SHALE FROM LOCALITIES WEST OF THE BLACK HILLS

A sample of the Mowry shale collected near Winnett, Mont., about 250 miles northwest of the Black Hills region, by Frank Reeves, of the United States Geological Survey, was examined for comparison with the Black Hills material. In the hand specimen it consists of alternations of very hard dark-gray clay beds one-

\footnotetext{
${ }^{30}$ Iddings, J. P., Rock minerals, p. 593, New York, 1911 .
${ }^{40}$ Van Hise, C. R., A treatise on metamorphism: U. S. Geol. Survey Mon. 47, p. 16, 1904 .
}

eighth inch thick, with light-gray, very fine-grained sandstone beds one-fourth inch thick. Fragments of fish scales and bones are abundant. According to Mr. Reeves, the thin-bedded alternation is typical of the Mowry of this region, but toward the west the sandy layers become thicker. Microscopic examination shows that the grains in the sandy layers are less than 0.2 millimeter in diameter and average about 0.04 or 0.05 millimeters. The sand grains consist of angular quartz (some of which show secondary enlargement) and fresh orthoclase (and sanidine?), nearly 1 per cent of rounded crystals of zircon, and some magnetite, hornblende (?), and cryptocrystalline material. The cement appears to be cryptocrystalline quartz. The clay beds contain a small percentage of fine sand and silt, and in every respect greatly resemble the Mowry shale of the Black Hills.

Near the Highwood Mountains, in northwestern Montana, about 350 miles northwest of the Black Hills region, a hard light-colored cherty volcanic ash occurs in the Colorado shale at a stratigraphic position near or perhaps somewhat below that of the Mowry shale." This bed, about 30 feet thick, is "pale yellowish gray, weathering white. It resembles porcelain and is overlain by rock of similar character and appearance." 42 In one thin section examined by Johannsen the rock was seen to be "cryptocrystalline in texture. It is very slightly anisotropic, as a devitrified glass might be. There are a few irregular anisotropic patches which are too small to be determined. There is also a little brownish decomposed material." In another section the rock was "a very fine-grained, compact glass, consisting almost en tirely of angular fragments very slightly devitrified, and a very few small, irregular grains, apparently of quartz, but too small to be determined. The rock is very homogeneous and uniform in appearance throughout the section." ${ }^{43}$ Although this ash may not be an exact correlative of the Mowry shale, these descriptions indicate that it has several megascopic and microscopic characteristics in common with that member.

A thin section of a sample of the Mowry shale from Vermilion Creek, Colo., about 250 miles southwest of the Black Hills region, collected by W. H. Bradley, of the United States Geological Survey, was also examined. According to Mr. Bradley and other members of the Geological Survey, the Mowry shale in that region resembles hand specimens of the Mowry from the Black Hills and contains very little if any sandstone. Microscopically Mr. Bradley's sample is almost identical with specimens of the Black Hills Mowry. Less than 5 per cent of the grains have diameters greater than about 0.005 millimeter, and the largest

41 Reeves, Frank, personal communication.

${ }^{42}$ Fisher, C. A., Geology of the Great Falls coal field, Mont.: U. S. Geol. Survey 42 Fisher, C. A., Geold
Bull. 356 , p. 37,1909 .

Bull. 356, p. 37, 1909.
43 Johannsen, Albert, in Fisher, C. A., idem, p. 37. 
grain noted was 0.12 millimeter across. Much opal or glass is present, and cavities filled with microcrystalline chalcedony and round organisms similar to those in the Black Hills specimens were noted. There is also a large amount of dark organic matter.

Except for interlaminated sandy material in $\mathrm{Mr}$. Reeves's specimen from Montana, the samples of Mowry shale from western localities closely resemble those from the Black Hills region. However, both the Montana and the Colorado specimens show some evidence of secondary silicification.

\section{UNCERTAIN ORIGIN OF THE SAND, SILT, AND CLAY}

The evidence is inconclusive as to whether the sand, silt, and clay that make up about one-fourth of the total weight of the Mowry shale are normal clastic sediments or derivatives from volcanic ash, but it seems probable that both sources have contributed.

The angularity, freshness, and small amount of the sand and silt in the Black Hills Mowry, the fairly uniform maximum diameter (0.2 millimeter) of the grains in all specimens, the sanidine and volcanic glass and the general association with altered volcanic ash suggest that the coarse material may be crystalline minerals from ash instead of ordinary clastic sand. The associated bentonite contains nearly as much crystalline material as the typical Mowry shale, and the sandy beds might be crystal tuff, which is reported to be a common product from acidic magmas. ${ }^{44} \mathrm{Al}$ though the rounded form of the zircon crystals in Reeves's specimen may be the result of resorption in the magma, ${ }^{45}$ abrasion seems a more probable explanation. This probable abrasion and the increase in amount of sandy material northwestward from the Black Hills suggest that a large part of the sand grains were normal clastic sediments.

The angularity and freshness of nearly all the sand and silt grains in the Mowry shale show that these grains have undergone very little abrasion and chemical weathering, and if they are not volcanic, they are difficult to explain. They may have been disintegrated in an arid or cold climate and deposited near by, thus escaping chemical decomposition and rounding, or they may have been broken from sea cliffs, protected from weathering by immediate submersion, and scattered widely in a shallow agitated sea. Admittedly neither alternative seems very satisfactory, but it is conceivable that the second one may explain the coarse material in the Mowry shale.

The determinable optical properties of the clay mineral and the striking similarity of the analyses suggest that the clay in the Mowry shale may be the bentonite mineral montmorillonite, derived from the alteration

\footnotetext{
4 Pirsson, I. V., The microscopical characters of volcanic tuffs: Am. Jour. Sci., 4th ser., vol. 40, p. 199, 1915.

is Armstrong, $P_{\text {., }}$ Zircon as criterion of igneous or sedimentary metamorphics: Am. Jour. Scl., 5th ser., vol. 4o pp 391-395, 1922.
}

of ash. Yet the contained carbonaceous matter shows that the conditions of accumulation were different from those giving rise to bentonite and that at least some material other than ash was deposited. This evidence and the absence of the general characteristics of bentonite suggest that the clay in the Mowry may have been merely a normal mechanical sediment.

It seems probable that the sand, silt, and clay, estimated to make up about one-fourth of the Mowry shale of the Black Hills region, are partly more or less altered volcanic ash and partly normal clastic sediments. The writer sees no evidence indicating which of these two possible sources was most effective in the accumulation of this material.

\section{SUMMARY OF MICROSCOPIC EVIDENCE}

Microscopic examinations of the Mowry shale demonstrate the improbability of some of the explanations of its origin suggested by field relations and chemical analyses. It is seen, for example, that the siliceous character is not due to large quantities of quartz sand but that it has probably been derived from amorphous substances such as opal and volcanic ash. Approximately one-third of the rock is apparently cryptocrystalline quartz derived from opaline (chemically precipitated) silica. The remainder seems to be devitrified ash, carbonaceous clay, sand, and silt. The sand, silt, and clay, roughly one-fourth of the rock, may be partly volcanic and partly normal clastic material.

\section{PREVIOUS INVESTIGATIONS}

\section{SUGGESTIONS AS TO ORIGIN OF MOWRY SHALE}

Several theories of the origin of the Mowry shale have been proposed. Billingsley, ${ }^{46}$ discussing especially the Mowry of Montana, interpreted the member as simply a fine-grained sandstone deposited during a sudden shoaling of the sea. Reeves, ${ }^{47}$ likewise considering the Mowry of Montana, came to the similar conclusion that it is a very fine-grained sandstone "probably washed in a shallow sea and widely distributed by wave and current action."

Washburne, ${ }^{48}$ in discussing a paper by Rae, ${ }^{49}$ cites the Mowry as an "impure shaly chert" containing "a few spicules of Radiolaria but no diatoms" and formed by the "primary precipitation on the sea bottom of colloidal silica with much organic matter and other sediment." Rae, noting the relation between the amount of organic matter and free silica in river waters, had suggested that the source material

${ }^{46}$ Kemp, J. F., and Billingsley, Paul, Sweet Grass Hills, Mont.: Geol. Soc. America Bull., vol. 32 , pp. $473-475,1921$

${ }^{47}$ Reeves, Frank, Geology and possible oil and gas resources of the faulted area south of the Bearpaw Monntains, Mont.: U. S. Geol. Survey Bull. 751, p. 89, 1924.

13 Washburne, C. W., Am. Assoc. Petroleum Geologists Bull., vol. 7, p. 441, 1923

19 Rae, C. C., Organic material of carbonaceous shales: Am. Assoc. Petroleum Geologists Bull., vol, 6, pp. 333-341, 1922; A possible origin of oil: Am. Inst. Min. and Met. Eng. Trans., vol, 68, pp. 1112-1120, 1923. 
of oil may have been precipitated chemically by sea water. Washburne suggests that the siliceous character of the Mowry and its association with oil in Wyoming may be explained by Rae's theory. Cunningham, ${ }^{50}$ in a paper developing Rae's theory of the origin of oil in California, suggested that the great number of fish scales in the Mowry shale might be explained by a high mortality among fishes due to the poisonous effect of decomposing organic material upon the sea floor.

Geis, ${ }^{51}$ who studied the Mowry shale in several areas, found that the weathered surface is "composed largely of the remains of organisms, especially of diatoms and Foraminifera," and that at several localities "volcanic ash forms a minor portion of the mass." He recognized a sandy phase of the member and noted a relation between the amount of sand in the Mowry and the quality of the oil produced in a region. From this relation, the fact that the geographic distribution of the Mowry shale and the light oil fields of the Rocky Mountain region coincide, and the stratigraphic distribution of Wyoming oil fields, he concluded that the Mowry shale was an important source of oil. It is of interest to observe in this connection that Estabrook ${ }^{52}$ found that on the average the gravity of Wyoming oil increases both upward and downward from the horizon of the Mowry shale. In discussing the origin of the Mowry, Geis does not mention the hardness of the "shale, although it seems that he may attribute it to the presence of sand and siliceous tests of diatoms. He interprets the Mowry simply as a normal shale rich in organic matter.

Macfarlane, ${ }^{53}$ endeavoring to prove that oil is derived from fish remains, contends that essentially all oil in the Cretaceous rocks of western North America came from fishes, which were abundant during the deposition of the Mowry shale and were killed and preserved by numerous falls of volcanic ash. Henderson ${ }^{54}$ criticizes this contention sharply and points out that the fishes were thoroughly decomposed and their scales scattered before burial. He also suggests that the general scarcity of calcareous shells and bones in the Mowry may be due to the presence of organic acids produced by the decomposition of algae in the water in which the shale was deposited.

Hewett ${ }^{55}$ noted that the Mowry shale of the Big Horn Basin "probably contains considerable volcanic glass."

\footnotetext{
so.Cunningham, G. M., Were diatoms the chief source of Californis oil?: Am. Assoc. Petroleum Geologists Bull., vol. 10, p. 714, 1926.

s1 Geis, W. H., The origin of light oils in the Rocky Mountain region: Am. Assoo. Petroleum Geologists Bull., vol. 7, pp. 499-504, 1923.

62 Estabrook, E. L., Occurrences of oil and gas in Wyoming: Am. Assoc. Petroleum Geologists Bull., vol. 8, 515, 1924.

s3 Macfarlane, J. M., Fishes the source of petroleum, pp. 223-256, New York, Macmillan Co., 1923

34 Henderson, Junius, Sources of material from which petroleum may have been derived: California Acad. Sci. Proc., vol. 15, pp. 273-275, 1926.

s5 Hewett, D. F., Geology and oil and coal resources of the Oregon Basin, Meeteetse, and Grass Creek Basin quadrangles, Wyo.: U. S. Geol. Survey Prof. Paper 145 , p. $54,1926$.
}

The explanation of the origin of the Mowry shale suggested by Billingsley and Reeves, although possibly satisfactory for the sandy Montana phase, does not account for the unusual character of the fine-grained shale of Wyoming. The organic content of the shale and its relation to occurrences of oil, as noted by Washburne and Geis, are in themselves not adequate explanations of the peculiarities of the Mowry. Cunningham's suggested explanation of the abundance of fish scales seems improbable, for unless the poisons were introduced suddenly and repeatedly it is difficult to account for the repeatedly renewed supply of fishes over so large an area. Siliceous organisms, if commonly present in such abundance as the diatoms found by Geis, might possibly be a satisfactory source of the silica. However, the writer's investigations indicate that in other places only' a small number of either diatoms or radiolarians occur in the formation.

It seems unnecessary to assume, as Henderson has, that in order to dissolve out the carbonates the sea water must have contained acids derived from plant decay, for merely slow sedimentation would account for the solution of these carbonates. The solubility of calcium carbonate in sea water depends almost entirely upon the carbon dioxide content of the water. This carbon dioxide content, in turn, depends upon the amount of carbon dioxide available in the adjacent atmosphere and on the sea floor and upon the temperature of the water. ${ }^{56}$ The colder the water the greater the quantity of carbon dioxide the water can contain, and the greater the carbon dioxide content the more calcium carbonate the water is capable of dissolving. Careful determinations indicate that, considering the temperature, the carbon dioxide content of the surface water of the ocean in tropical and temperate climates is approximately in equilibrium with the atmosphere, and that this surface water is essentially saturated with calcium carbonate..$^{57}$ If more calcium carbonate were somehow added it would be precipitated.

Sea water normally becomes colder with increasing depth, and hence the deeper water is capable of holding more carbonate in solution than the warmer surface water. This means that the deeper colder water would dissolve additional calcium carbonate if any was available until it became saturated. Calcium carbonate precipitated in the surface waters by whatever agencies and falling into the deeper water would be redissolved unless quickly buried. The effectiveness of the thermal gradient of sea water in causing solution of carbonates on the bottom of the ocean is shown by the local saturation of water in contact with the bottom ${ }^{58}$ and

Wells, R. C., The solubility of calcite in water in contact with the atmosphere and its variation with temperature: Washington Acad. Sci. Jour, vol. 5 , pp. 617622 , 1915. Johnston, John, and Williamson, E. D., The rôle of inorganic agencies in the deposition of calcium carbonate: Jour. Geology, vol. 24, pp. 729-750, 1916.

si Johnston, Johr, and Williamson, E. D., op. cit., pp. 734-735.

5s Wells, R. C., New determinations of carbon dioxide in water of the Gulf of Mexico: U. S. Geol. Survey Prof. Paper 120, p. 11, 1919. 
by the corrosion and re-solution of shells collected from deep water. ${ }^{59}$ If the rate of burial of the calcareous material on the bottom is rapid, or if circulation and diffusion are so slow that the bottom waters become and remain saturated, carbonates could accumulate. However, regardless of circulation, if the rate of sedimentation were sufficiently slow, calcium carbonate would be dissolved from the sea floor. Especially would this be true where, as during the deposition of the Mowry shale, abundant carbon dioxide was evolved by decaying organic matter on the sea bottom. As is discussed somewhat more fully under the heading "Conclusions," the thickness of the laminations, the condition of the organic matter, and other evidence indicate that the Mowry shale accumulated very slowly. It thus seems simplest and most in accord with the facts to attribute the absence of carbonates in the Mowry shale to a slow rate of sedimentation.

Washburne's theory that the silica was deposited colloidally on the sea floor is of these suggestions the only direct attempt to explain the high silica content of the Mowry shale. This theory, expanded to include Rae's proposed explanation of the origin of oil, is a fairly comprehensive interpretation of the origin of the Mowry shale. However, it does not adequately account for the observed relation of the shale to altered volcanic ash. Also most of the organic matter is in distinct if decayed fragments, and only a small part has a structure such as might result from colloidal precipitation, and it therefore seems that very little if any of this organic matter was precipitated as colloids.

THEORIES OF ORIGIN OF OTHER SILICEOUS FORMATIONS, INCLUDING " MONTEREY SHALE" OF CALIFORNIA

An imposingly large, controversial literature on the origin of chert might be cited for suggestions as to the origin of the silica in the Mowry shale. These various theories of the deposition of silica fall into two major groups, in one of which it is regarded as contemporaneous with and in the other as subsequent to sedimentation. Each group is further subdivided into classes of special theories. The contemporaneous or syngenetic group postulatesnormal clastic, biochemical, magmatic, or direct chemical deposition of the silica. The so-called pene-contemporaneous theory, which is more or less intermediate between the two major groups, assumes that the precipitation occurred later than sedimentation but before consolidation of the inclosing rocks. The subsequent or epigenetic group comprises two general types of theories-that the silica was deposited while the rock was in the zone of cementation and that it was deposited while it was in the zone of weathering.

s9 Murray, John, and Renard, A. F., Challenger Rept., Deep-sea deposits, pp 276-280, 1891. Willis, Bailey, Conditions of sedimentary deposition: Jour. Geology, vol. 1, pp. 504-507, 1893. Clarke, F. W., The data of geochemistry, 5th ed.: U. S. Geol. Survey Ball. 770, p. 132, 1924.
Most theories of the origin of chert have been developed to explain nodular masses in calcareous rocks, a type of occurrence of silica very different from that in the Mowry shale. However, nearly all the theories have at some time been applied to bedded cherts, a type of occurrence in some respects similar to that in the Mowry shale. A few examples of bedded cherts that have been rather thoroughly studied will be cited.

Several geologists have discussed the origin of the "Monterey shale" of California, a widespread thick series of hard siliceous shale forming the major part of the Monterey group of current nomenclature, the distribution of which closely coincides with occurrences of oil. The Monterey group contains flinty chert, limestone, sandstone, diatomaceous earth and acidic tuff, but the predominant lithologic type is a siliceous shale in which diatoms and fish scales are common and Foraminifera, Radiolaria, and bone fragments occur. Under the microscope the rock seems to be made up of amorphous and microcrystalline silica surrounding angular quartz grains. ${ }^{60}$ In its dominant lithologic character, wide distribution, association with occurrences of oil and volcanic ash, microscopic appearance, chemical composition (see analysis 8), and content of fish scales and some Radiolaria the "Monterey shale" resembles the Mowry. However, in many other respects the two are dissimilar.

From the abundance of organisms in certain portions of the series, the "Monterey shale" had been thought to be made up of the siliceous remains of diatoms, radiolarians, and sponges. Lawson, ${ }^{61}$ thinking this explanation inadequate, noted that the small amount of crystalline material in the shale is fresh and angular, that these minerals are those of an acidic volcanic rock, and that the chemical composition of the shale corresponds to that of a very acidic soda rhyolite. He therefore suggested tentatively that the shale was derived largely from volcanic glass dissolved by sea water and chemically precipitated as pulverulent or gelatinous silica. This hypothesis seems to have been disregarded by later writers. Fairbanks ${ }^{62}$ suggested that the "Monterey shale" was formed by the crystallization of diatomaceous shale. Arnold and Anderson, ${ }^{63}$ noting that diatoms probably constitute less than 10 per cent of the rock in even the most fossiliferous shales and that these most fossiliferous shales are the least siliceous, concluded that the chief agents in hardening were infiltrated siliceous waters. Davis ${ }^{64}$

\footnotetext{
${ }^{B 0}$ Arnold, Ralph, and Anderson, Robert, Geology and oil resources of the Sant Maria oil district, Calif.: U. S. Geol. Survey Bull. 322, pp. 33-47, 1907 . For a review of the stratigraphy of the Monterey group see Louderback, G. D., The Monterey series in California: California Univ. Dept. Geology Bull,, vol. 7, pp. 177-241, 1913

61 Lawson, A. C. The geology of Carmelo Bay: California Univ. Dept. Geology Bull., vol, 1, pp. 24-28, 1893.

${ }^{62}$ Fairbanks, H. W., U. S. Geol. Survey Geol. Atlas, San Luis folio (No. 101), p. 4, 1904 .

63 Arnold, Ralph, and Anderson, Robert, op. cit., pp. 46-47.

of Davis, E. F., The radiolarian cherts of the Franciscan group: California Univ. Dept. Geology Bull., vol. 11, p. 298, 1918.
} 
considered secondary silicification but dismissed it as untenable and concluded that the siliceous portions of the "Monterey shale"" were deposited originally as gelatinous silica that was derived from some source other than the diatoms. Heim ${ }^{65}$ ascribes the absence of lime, the abundance of diatoms, the regularity of stratification, and the scarcity of sand to sedimentation in a cold longshore current on a rather deep ocean floor. Rae ${ }^{66}$ cited the siliceous and bituminous shales of California as possible examples of his theory that silica and the mother substance of oil are precipitated colloidally by sea water, and this idea has been developed further by Cunningham. ${ }^{67}$ English ${ }^{68}$ considered the diatoms an inadequate source of the silica and suggested that an original siliceous mud, derived clastically and chemically from the decay of a rhyolitic land mass, would account for it. He also mentioned the possibility that its siliceous character might be due to the presence of fine ash. At a symposium on "Siliceous shale and the origin of oil in California" held by the Cordilleran section of the Geological Society of America in January, $1926,{ }^{69}$ Hoyt S. Gale suggested that the volcanic material in the shale made the sea water rich in silica and thus furnished a favorable habitat for the diatoms.

Though different from the Mowry shale in many respects, the radiolarian cherts of the Franciscan also repay consideration, because of the careful attempts that have been made to interpret their origin. In addition to the radiolarian cherts, the Franciscan, which like the Monterey is restricted to California, contains sandstone, limestone, pillow basalts, and schist.

The Franciscan cherts haa long been considered metamorphic rocks, but Ransome ${ }^{70}$ discovering the presence of radiolarians, concluded that the rocks are sedimentary deposits which are siliceous because of the contained organisms. Lawson ${ }^{71}$ considered the silica an amorphous chemical precipitate formed on the ocean floor and concluded that siliceous springs were most probably the source of this silica. In an exhaustive study, including an extensive review of the literature of radiolarian cherts, Davis ${ }^{72}$ considered many possible explanations and concluded that Lawson's suggestion, despite certain criticisms that had been made of it, appeared most probable.

\footnotetext{
es Heim, Arnold, Notes on the Tertiary of southern Lower California (Mexico): Geol. Mag., vol. 59, p. 539, 1922; Über submarine Denudation und chemische Sedimente: Geol. Rundschau, Band 15, p. 35, 1924.

of Rae, C. C., A possible origin of oil: Am. Inst. Min. and Met. Eng. Trans., vol. 68, pp. 1118-1119, 1923.

67 Cunningham, G. M., op. cit., pp. 709-719.

${ }^{03}$ Euglish, W. A., Geology and oil resources of the Puente Hills region, southern California U S. Geol. Survey Bull. 768, pp. 31-33, 1926.

69 Heald, K. C., Annual meeting of the Cordilleran branch of the Geological Society of America: Am. Assoc. Petroleum Geologists Bull., vol. 10, pp. 449-450, 926.

70 Ransome, F. L., The geology of Angel Island: California Univ. Dept. Geology Bull., vol. 1, pp. 199-200, 1894 .

71 Lawson, A. C., Sketch of the geology of the San Francisco Peninsula: U. S. Genl. Survey Fifteenth Ann. Rept., pp. 425-426, 1995.

72 Davis, E. F., op cit., pp. 235-432.
}

In a recent discussion of the origin of a bedded radiolarian chert associated with pillow lavas and acidic tuffs, Sampson ${ }^{73}$ emphasized the widespread and intimate association of cherts with pillow lavas and tuffs as recorded in the literature. He concluded that the chert he studied was formed largely by the inorganic precipitation of silica which came from submarine springs.

Honess ${ }^{74}$ found that at least a part of the Arkansas novaculite, a thick series of hard siliceous rocks similar to chert, is silicified and devitrified volcanic ash.

Cathcart ${ }^{75}$ has recently found that a very thick series of Triassic (?) cherts in Nevada show all stages of gradation into fine-grained volcanic tuffs. Some of his hand specimens and thin sections of this material were examined by the writer and found to bear rather striking resemblances to samples of the Mowry shale. This series of Triassic (?) cherts may be the same as a series of siliceous rocks exposed about 50 miles to the southeast which Hill ${ }^{76}$ found to be largely volcanic tuffs.

\section{CONCLUSIONS AS TO PROBABLE ORIGIN OF MOWRY SHALE}

The field, chemical, and microscopic evidence converge in indicating that the Mowry shale of the Black Hills region is somehow related to altered volcanic ash. This conclusion is strengthened by the common association of bedded siliceous rocks elsewhere with volcanic materials. The evidence indicates that the Mowry shale consists of volcanic ash, clay, silt, sand, and organic matter and a large amount of chemically precipitated silica. The most probable causes of deposition of this silica that have emerged from the foregoing discussions account for it as either (1) secondary, having been deposited after the accumulation of the mechanical sediments by $(a)$ weathering at the outcrop or $(b)$ consolidation-solution at the contacts of glass particles and deposition in pore spaces; or (2) contemporaneous, having been deposited with the clastic sediments, from sea water rich in silica, by the decay of organic matter or by other precipitating agents in the sea.

\section{SECONDARY DEPOSITION OF SILICA}

The absence of unusual precipitating agents in the Mowry shale and the conclusion that silicification by bentonite or by the interaction of two ground waters was unlikely have apparently reduced the probable methods of secondary deposition to two:

Weathering at the outcrop.-Without going into a detailed discussion of solution and deposition of silica

${ }^{73}$ Sampson, Edward, The ferruginous chert formations of Notre Dame Bay Newfoundland: Jour. Geology, vol. 31, pp. 571-598, 1923.

74 Honess, C. W., Geology of the southern Ouachita Mountains of Oklahoma: Oklahoma Geol. Survey Bull. 32, pp. 121-139, 1923.

${ }^{75}$ Ferguson, H. G., and Cathcart, S. H., Hawthorne quadrangle, Nevada: U. S. Geol. Survey Prof. Paper (in preparation).

${ }^{76}$ Hill, J. M., Some mining districts in northeastern California and northwestern Nevada: U. S. Geol. Survey Bull. 594, pp. 172-174, 1915. 
by evaporation and leaching of other constituents of a rock, it is sufficient to note that without some outside source this method of silicification can be effective only in a rock already high in silica. There is no suggestion of an adequate source of silica near the Mowry shale, and the problem is no nearer solution if it is assumed that the shale was rich in silica before weathering. Furthermore, well cuttings show that even far underground the formation is more siliceous than the adjacent shales. Field evidence indicates that some silicification takes place at the outcrop, but other considerations apparently prove it to be only a minor factor.

Consolidation-solution at the contacts of glass particles and deposition in pore spaces.-If the writer's estimate is correct that less than one-half of the Mowry shale is precipitated silica, secondary deposition is within the bounds of possibility, for an accumulation of small highly angular fragments of glass might have a porosity of 50 per cent or even more. As the accumulation became more deeply buried, solution at the contacts of sharp edges and precipitation in the pores would be expected. However, according to this hypothesis, the ash was extremely angular at the time of deposition, and the precipitation of cement should have preserved the original surfaces of the glass particles next to the pores. The fact that very few such sharp margins were found but that on the contrary a few apparently residual masses of opal were seen considerably weakens the hypothesis. The uncrushed condition of the delicate radiolarian test (see pl. 16, $A$ ) indicates that the shale has undergone much less compacting than this hypothesis seems to demand. If this explanation were correct the precipitated material should consist of the less soluble constituents of the glass, chiefly alumina and silica, but analyses and microscopic evidence indicate that the added material is silica without appreciable amounts of alumina. Moreover, the hypothesis does not explain the alternation of the layers of microcrystalline quartz and more argillaceous material. Nor does it account for the physical differences between the Mowry shale and bentonite; as both were presumably derived from the same ash, the purer ash beds should by this hypothesis have formed harder rock instead of bentonite. Although this method of consolidation may have been a factor in the silicification of the Mowry shale, it seems extremely unlikely that it was more than a very minor one.

\section{CONTEMPORANEOUS ORIGIN OF SILICA}

The most probable hypotheses of contemporaneous origin call for a sea water that contained an adequate supply of silica and substances that would cause the precipitation of silica. The silica originally in the sea water might have come from river waters rich in silica, ${ }^{77}$ from submarine springs, or from the solution

\footnotetext{
$n$ Tarr, W. A., Origin of the chert in the Burlington limestone: Am. Jour. Sci., 4th ser., vol. 44, pp. 428-432, 1917.
}

of a siliceous volcanic ash. Siliceous organisms are not considered a likely source because they are very. uncommon in the specimens examined by the writer and because their excellent state of preservation (see pl. 16, $A$ ) would be very difficult to explain had the cryptocrystalline matrix also been derived from siliceous organisms. Moreover, such organisms merely use silica already present.

The precipitation of silica might have been brought about by silica-secreting organisms, by electrolytes in the sea water, or by compounds derived from the decay of nitrogenous organic matter (animals and microscopic plants). Siliceous organisms obtain the material for their tests from suspended clay particles in the sea rather than from dissolved silica, ${ }^{78}$ and water that contained large quantities of suspended silicates and siliceous organisms might deposit much silica biochemically. Under certain conditions the remains of these tests might be dissolved on the sea floor and precipitated as amorphous silica. However, as mentioned in the preceding paragraph, the excellent state of preservation of the Radiolaria in the Mowry shale makes it seem extremely improbable that any such process of solution and deposition acted upon siliceous tests to form the cryptocrystalline matrix. Organic precipitation seems improbable, but electrolytes present in normal sea water are capable of precipitating silica ${ }^{79}$ and ammonium carbonate, a compound especially effective in coagulating silica, and bicarbonates were almost certainly abundant while the organic matter now present in the Mowry shale decayed.

It has been concluded in the foregoing discussions that the original ash in the Mowry shale and that in the associated bentonite beds were nearly identical in composition and that the presence in the Mowry of the clay, silt, and especially the organic matter and precipitated silica constitutes the only important difference in the composition of the two rocks. These associated materials, therefore, might be expected to explain why some of the ash formed siliceous shale and and some altered to bentonite.

Beds of bentonite that are nearly free from organic or other impurities probably represent individual ash falls. Organic matter of any sort is very uncommon in bentonite. The writer found no fossils in the bentonite beds associated with the Mowry shale, and the sole occurrence of fossils in any bentonite bed known to him consists of some invertebrate remains in a persistent bed of fairly pure bentonite in the middle of the Belle Fourche member of the Graneros shale. Here, in the W. $1 / 2$ sec. 19, T. 57 N., R. 66 W., Crook County, Wyo., the writer found abundant shells of a smooth simple form of Ostrea and some crustacean fragments ${ }^{80}$ in a 1-inch layer of prismatic and cone-

${ }_{78}$ Murray, John, and Irvine, Robert, On silica and the siliceous remains of organisms in modern seas: Roy. Soc. Edinburgh Proc., vol. 18, pp. 244-250, 1891.

70 Tarr, W. A., op. cit., pp. 434-437.

60 Identiffcation by J. B. Reeside, jr. 
in-cone calcium carbonate in the upper part of a bentonite bed 4 feet thick. The very small amount of organic matter in most bentonite beds suggests, though it by no means proves, that the original ash accumulated so rapidly that the organisms were obscured by the large proportion of contemporaneous sediments.

This possibilty of a relatively rapid rather than a gradual accumulation of the ash that formed bentonite is considerably strengthened by examinations of the sand-sized material in bentonites from the Black Hills region. Wherry ${ }^{81}$ found a marked decrease upward in the amount of feldspar, biotite, and magnetite in a bed of bentonite near the. base of the Pierre shale in southwestern South Dakota. He explained this decrease by the difference between the settling velocities of these crystalline minerals and the extremely angular bubble-filled particles of volcanic glass. The bentonite bed at the top of the Mowry shale also shows this distribution of the crystalline minerals, for the present writer found a fairly uniform decrease upward in the percentage of sandsized material in seven samples constituting a vertical section of the bed near Upton, Wyo. This distribution indicates that the thick bed of bentonite at the top of the Mowry represents the deposit of a single ash fall. Furthermore, the small amount of obviously detrital sand grains in most bentonites and particularly in those associated with the Mowry shale tends to support the assumption of relatively rapid deposition.

Unlike the associated bentonite, the Mowry shale itself contains much organic material. The large amount of this material suggests that it required a long time to accumulate. The disintegrated condition of the organic matter, the abundance of the chemically resistant fish scales, and the absence of easily soluble carbonates indicate that this débris was long exposed to decay and submarine solution. If, as seems a reasonable assumption, the thin laminae in the shale are annual layers, ${ }^{82}$ the Mowry shale accumulated in about half a million years. This would mean that the ash that formed the bentonite was deposited several thousand times as rapidly as the material that formed the shale. These several lines of evidence make it seem justifiable to assume that the shale with its contained ash accumulated very slowly and that this ash, unlike that which altered to bentonite, lay for a long time on the sea floor in contact with water. This suggested difference in the length of time the ash in the two rocks lay exposed to sea water affords a possible clue to the origin of the Mowry shale.

81 Wherry, E. T., Clay derived from volcanic dust in the Pierre in South Dakota: Washington Acad. Sci. Jour., vol. 7, pp. 579, 582, 1917.

82 Rubey, W. W., manuscript report on the lithologic character, rate of deposition, and organic content of Cretaceous shales from the Black Hills region (to be published by U. S. Geol. Survey); Possible varves in marine Cretaceous shale in Wyoming [abstract]: Washington Acad. Sci. Jour., vol. 18, pp. 260-262, 1928.
Another minor but perhaps significant difference between the two rocks is the greater size of the original ash particles in the bentonite, as indicated by the maximum diameters of the unaltered crystalline material.

\section{PROPOSED INTERPRETATION OF ORIGIN OF MOWRY SHALE}

An acidic volcanic dust contains an unusually large proportion of the most soluble constituents in igneous rocks-the alkalies, sodium and potassium-and as the small size and extreme angularity of its particles facilitate solution, water immediately in contact with the dust would become alkaline. Silica, the chief constituent of volcanic dust, though slightly soluble in pure water, is much more so in alkaline solutions..$^{83}$ The particles of ash would therefore be attacked by the locally alkaline water; the glass particles, if unusually small and not soon buried by later sediments, would be partly dissolved; and the water on the sea floor would become rich in silica. Ammonium carbonate from decaying organic matter or electrolytes in the sea water would probably precipitate a portion of this silica as a gel.

That some such subaqueous decomposition of volcanic glass into amorphous silica takes place is indicated by experimental and observational data. Cushman ${ }^{84}$ found that powders of rock that contain alkalies, especially the powders of noncrystalline materials such as artificial glass, when immersed in water give an alkaline reaction and are decomposed, with blurring of the outlines of fragments and the formation of colloidal silica or silicates. Dimbleby and Turner ${ }^{85}$ showed that the chemical instability of artifical glasses in water increases with an increase in the proportion $0 i \mathrm{Na}_{2} \mathrm{O}$ in the glass. The presence of hydrated silica associated with glass in volcanic muds on the sea floor ${ }^{86}$ indicates that a similar decomposition occurs in nature.

Though both electrolytes and decaying organic matter might have precipitated the silica, the details of the relation between the hardness of the Mowry shale and bentonite beds suggest that decaying organic matter was the more effective. The proportion of electrolytes in sea water would be essentially unaltered by an ash fall, and if electrolytes were the principal coagulating agents, hardened shale would be expected just above even the thickest bentonite beds, for the top of the ash bed would have been long exposed to the chemical action of electrolytes. On the contrary, the Mowry shale is hardest just below each bentonite bed and quite unsilicified above the last and thickest one.

${ }_{83}$ Lovering, T. S., The leaching of iron protores; solution and precipitation of silica in cold water: Econ. Geology, vol. 18, pp. 524-533, 1923. Also common laboratory practice is based on this fact.

s4 Cushman, A. S., The effect of water on rock powders: U. S. Dept. Agr. Bur. Chemistry Bull. 92, pp. 5-24, 1905.

${ }_{85}$ Dimbleby, Violet, and Turner, W. E. S., The relationship between chemical composition and the resistance of glasses to the action of chemical reagents: Soc. Glass Technology Jour., vol. 10, pp. 304-358, 1926.

${ }_{86}$ Murray, John, and Renard, A. F., Challenger Rept., Deep-sea deposits, pp. 243244,1891 . 
This relation might be explained by assuming that the organic débris on the sea floor was quickly buried by the ash falls, that many organisms were killed by each fall, that between eruptions they recovered slowly to their former abundance, and that the final, largest fall virtually exterminated them. A further objection to the general idea of precipitation by electrolytes, raised by Dean, ${ }^{87}$ is that the electroylytes would be the principal material adsorbed by the silica and hence form the chief impurity in the siliceous rock.

Other factors than the effect of ash falls upon organisms must also have contributed to bring about the upward increase in silica content of the Mowry shale and the change in conditions of sedimentation from Mowry to Belle Fourche time. There is some evidence in the stratigraphic distribution of bentonite beds in the Mowry shale that ash falls became progressively more frequent or that there was less and less normal sedimentation between large ash falls until the end of Mowry deposition. Therefore the progressive upward increase in silica content may be in large part due to greater quantities of highly siliceous ash or to longer exposure to decomposition by sea water. It is also possible that a small amount of the excess silica in the shale just below bentonite beds may be due to secondary silicification, even though this process could not account for all the excess silica at these horizons.

The theory that the Mowry shale was formed on the sea floor by the chemical decomposition of slowly accumulated, very fine grained, highly siliceous volcanic ash in the presence of decaying organic matter appears to account satisfactorily for the present physical differences between the shale and the bentonite, despite the fact that the exact changes involved in the alteration of ash to bentonite are not known. Large ash falls would accumulate very rapidly and perhaps contain larger particles, thus preventing much solution of silica, ${ }^{88}$ and, as organic remains would be practically absent, little silica would be precipitated. Between the more violent explosions small eruptions might occur frequently enough to distribute widely a small amount of fine volcanic dust, or ash from earlier falls might be washed into the sea and the finer fragments widely distributed. Altered by long exposure to the action of sea water and decaying organic matter and embedded with silica gel, this dust would form a rock quite different from bentonite.

It does not seem necessary to call upon river waters or submarine springs as a source of the silica, for an acidic volcanic ash would furnish an unusual amount,

\footnotetext{
"Denn, R. S., The formation of Missouri cherts: Am. Jour. Sci., 4th ser., vol. 45, p. $412,1918$.

${ }_{89}$ This is consistent with the findings of Miser and Ross (Miser, H. D., and Ross, C. S., Volcanic rocks in the Upper Cretaceous of southwestern Arkansas and southenstern Oklahoma: Am. Jour. Sci., 4th ser., vol. 19, p. 120, 1925; Ross, C. S., Miser II. D., and Stephenson, L. W., Water-laid volcanic rocks of early Upper Cretaceous age in southwestern Arkansas, southeastern Oklahoma, and northeastern Texas: U. S. Geol. Survey Prof. Paper 154, pp. 175 et seq., 1929), who found calcite concretions that contained unaltered tuff in bentonite beds and concluded that the alteration to bentonite was subsequent to the burial of the ash.
}

far from shore, and concentrated upon the sea floor more readily than diffusion and currents in water, and none of the evidence suggests local deposition near submarine springs.

The occurrence and excellent state of preservation of the Radiolaria may perhaps be explained by the unusually favorable conditions for the preservation of these incidental fossils.

It is consistent with this theory to interpret the thickening of the Mowry shale and its correlatives southwestward as evidence that the volcanoes from which the ash in the shale and bentonite was blown were situated near southwestern Wyoming. If this interpretation is correct, individual bentonite beds should likewise thicken southwestward toward the supposed source of the ash, but near-shore deposits might mask a portion of an ash deposit or split it with partings into thinner beds. In other ways also the thickness of a bentonite bed is not a reliable indication of the thickness of the original ash, for there were probably volumetric changes depending upon the degree of alteration and compacting. A more satisfactory test of the location of the volcanic vents would be the size of the included tuffaceous fragments.

The fine sand which thickens northwestward may be partly a normal clastic deposit derived from some source in central western Montana.

\section{SIGNIFICANCE OF RESULTS}

The evidence seems overwhelming that the origin of the Mowry shale is intimately connected with the occurrence of altered volcanic ash, and whether or not the proposed explanation of the silica in the shale is correct this occurrence of ash suggests possible applications to other problems.

Acidic tuffs may have been the source of silica in other siliceous formations, and this hypothesis seems worthy of consideration in further studies of the origin of chert and of such formations as the "Monterey shale" of California.

If it is true that the Mowry shale is a source of much oil, the interesting problem of the relation between the formation of oil and the conditions of deposition of the tuffaceous material is raised.

A most interesting application is stratigraphic. According to current correlations the deposition of the thicker Aspen formation of southwestern Wyoming began earlier than the Mowry epoch and continued through but not beyond it. This interpretation that the lower part of the Aspen is older than the lower part of the Mowry is based partly upon the greater thickness of the Aspen and partly upon the assumption that the top of the Bear River formation, which underlies the Aspen, is equivalent to the top of the Dakota sandstone, which in many places lies several hundred feet below the base of the Mowry. However, the presence of large quantities of volcanic ash in the original Mowry sediments makes it seem much more probable 
to the writer that the Mowry shale is the time equivalent of the Aspen formation. The greater thickness of the Aspen formation can be explained as due simply to thicker contemporaneous deposits near the source of the ash. This assumption could probably be tested, for tracing of individual bentonite beds-the most exact time markers available to stratigrapherswould show whether or not the limits of the Mowry shale vary sensibly from place to place. In southwestern Wyoming the Aspen formation is underlain by the Bear River formation, a thick unit of sandstone and shale carrying a fresh-water fauna. ${ }^{89}$ The exact age of the Bear River is unknown, as the paleontologic and stratigraphic evidence indicates merely that it is somewhat older than part of the Benton, but from its lithologic character and general stratigraphic position the formation has been tentatively correlated with the Dakota sandstone. In the absence of paleontologic evidence to the contrary, it seems more logical to correlate the volcanic débris of the Mowry and Aspen formations than the sandy material of the Dakota and Bear River formations, as has been done heretofore.

If the Mowry and Aspen formations can be considered strictly contemporaneous, they are valuable aids in interpreting the Cretaceous history of the Western Interior, for they can be used as a horizon marker in

.89.Stanton, T. W., The stratigraphic position of the Bear River formation: Am. Jour. Sci., 3d ser., vol. 43, pp. 98-115, 1892. that part of the Cretaceous system which yields little paleontologic basis for long-distance correlation.

The Dakota sandstone has long been referred to as a typical transgressing formation, yet, as it cuts across no reliable faunal zones, this interpretation is based solely upon its varying stratigraphic position with respect to other lithologic units, all of which may be in turn transgressive. If correct, the revised correlation here proposed would mean that the sandstone facies at the base of the Cretaceous called the Dakota sandstone transgresses upward and westward across Wyoming, as, from other evidence, it is generally thought to transgress upward and southward across the Great Plains.

The upper sandstone of the Dakota of northeastern Colorado, the Muddy sand of southeastern and central Wyoming, and the Newcastle sandstone of the Black Hills region have commonly been considered equivalents ${ }^{90}$ despite the fact that in Wyoming these sandstones occur well above the base of beds classified as Benton. As the Mowry shale almost immediately overlies these sandstones in Wyoming, it seems that a microscopic search for volcanic ash at the horizon of the Mowry in Colorado might be rewarded by new and definite evidence as to the equivalence of these sandstone beds throughout the general region.

po Stanton, T. W. Some problems connected with the Dakota sandstone: Geol. Soc. America Bull., vol. 33, pp. 264-269, 1922. Lee, W. T., Continuity of some oilbearing sands of Colorado and Wyoming: U. S. Geol. Survey Bull, 751, pp. 1-22, 1925. 